See discussions, stats, and author profiles for this publication at: https://www.researchgate.net/publication/276456512

\title{
Morphology of juvenile phase of Achelous spinimanus (Latreille, 1819) (Crustacea, Decapoda, Portunidae) reared in laboratory
}

Article in Journal of the Marine Biological Association of the UK - May 2015 DOI: $10.1017 / 50025315415000508$

\section{CITATIONS}

2 authors:

Eduardo Antonio Bolla Júnior

São Paulo State University

9 PUBLICATIONS 43 CITATIONS

SEE PROFILE
197

Maria Lucia Fransozo

São Paulo State University

139 PUBLICATIONS 2,199 CITATIONS

SEE PROFILE

Some of the authors of this publication are also working on these related projects:

Ocypodidae crabs biology View project

Biologia de Pachygrapsus transversus (Gibbes, 1850) (Crustacea, Brachyura, Grapsidae) na região de Ubatuba (SP) View project 


\title{
Morphology of juvenile phase of Achelous spinimanus (Latreille, 1819) (Crustacea, Decapoda, Portunidae) reared in laboratory
}

\author{
EDUARDO ANTONIO BOLLA JÚNIOR ${ }^{1,2}$ AND MARIA LUCIA NEGREIROS FRANSOZO ${ }^{2}$ \\ ${ }^{1}$ Instituto Federal de São Paulo, Av. Professor Celso Ferreira da Silva n. 1333, Jardim Europa, 18707-15o Avaré, São Paulo, Brazil, \\ ${ }^{2}$ NEBECC (Group of studies on crustacean biology, ecology and culture), Department of Zoology, Biosciences Institute, São Paulo \\ State University, 18618-970 Botucatu, São Paulo, Brazil
}

\begin{abstract}
The swimming crab Achelous spinimanus is an important fishery component of several countries in the Western Atlantic; therefore, knowledge of the different phases of its life cycle is essential for good management of this resource. The juvenile development of A. spinimanus was investigated in the laboratory, from megalopae captured in neuston samples at Ubatuba, São Paulo, Brazil (23 $\left.26^{\prime} S 46^{\circ} 09^{\prime} W\right)$, during the summer months of 2005-2007. Rearing was performed in a constant temperature $\left(25 \pm 1^{\circ} \mathrm{C}\right)$, filtered seawater from the collection location (35 psu) and natural photoperiod. We obtained nine stages of the juvenile phase. All the morphological characters that allow the recognition of the first juvenile stage were drawn and described, as well as the main alterations that occur in the following stages. The sexual differentiation based on the number of pleopods becomes apparent from the third stage on. Some important characters in the identification of the species at the juvenile phase are the number of segments on the exopod of antennule, on the antennal flagellum and on the palp of mandible, beyond the absence of pleopods (even rudimentary) in the first stage.
\end{abstract}

Keywords: Swimming crab, Brachyura, development, post-larval, immature

Submitted 22 January 2015; accepted 30 March 2015

\section{INTRODUCTION}

The superfamily Portunoidea Rafinesque, 1815 has numerous species of high ecological and economic importance, since they can act as water mass indicators (Taissoun, 1973). They constitute relevant fractions of fisheries of many countries in Europe, America and Japan (Paul, 1981; Román-Contreras, 1986; Hernández \& Ramírez, 1990; Mantelatto \& Fransozo, 1999; De Lestang et al., 2003; Sforza et al., 2010; Sahoo et al., 2011).

As part of this superfamily, recently, some American species of the genus Portunus Weber, 1795, belonging to the family Portunidae Rafinesque, 1815, have undergone taxonomic changes, supported by molecular studies (see Mantelatto et al., 2009). Among these species, we found Portunus spinimanus Latreille, 1819, P. spinicarpus (Stimpson, 1871), P. ordwayi (Stimpson, 1860), P. gibbesii (Stimpson, 1859) and P. rufiremus Holthuis, 1959, all these with occurrence in the Brazilian coast (Melo, 1996). Currently, such species belong to the resurrected genus Achelous De Haan, 1833 (previously, Achelous refers to a subgenus of Portunus).

The swimming crab Achelous spinimanus (Latreille, 1819) has wide distribution in the Western Atlantic: from New Jersey to the south of Florida (USA), Bermuda, Mexican Gulf, Antilles, Venezuela, Guiana and Brazil (from the states of Pernambuco to Rio Grande do Sul) (Melo, 1996). This

Corresponding author:

M.L. Negreiros Fransozo

Email: mlnf@ibb.unesp.br species lives in brackish waters of canals and bays, in different types of substrates such as sandy bottoms, gravel, broken shells and muddy, from the intertidal zone to $90 \mathrm{~m}$ depth (Melo, 1996). It is commercially sold for human consumption along the Brazilian coast, and is reasonably well studied with regard to several biological aspects, including population structure, morphometric and physiological maturity, fecundity and reproductive cycle (see Santos et al., 1995; Santos \& Negreiros-Fransozo, 1995, 1997, 1999).

A good taxonomic approach also requires knowledge of the early phases of life cycles of species, particularly those that show complex life cycles involving metamorphosis. Furthermore, such knowledge allows several studies such as ecological, physiological, biogeographic, amongst others (NegreirosFransozo et al., 2002; Anger, 2003; Marques et al., 2003; Figueiredo et al., 2008; Vergamini \& Mantelatto, 2008; Sotelo et al., 2009; González-Gordillo et al., 2010; Demain et al., 2011; Ragionieri \& Schubart, 2013; Bolla Jr et al., 2014).

Shen (1935) published the pioneer and detailed description of juvenile development in a brachyuran representative (the portunid Carcinus maenas (Linnaeus, 1758)), described up to the ninth juvenile stage. The subsequent descriptions were in their majority restricted to superficial descriptions of the first crab stage, although some authors remark on later stages.

Despite the fact that the superfamily Portunoidea has 455 living species (De Grave et al., 2009), few of them have been studied regarding juvenile development. In the family Geryonidae Colosi, 1923, Ingle (1979) described only the first juvenile stage of Geryon trispinosus (Herbst, 1803). With respect to the family Portunidae, the genus Callinectes 
Table 1. Achelous spinimanus (Latreille, 1819). Survival, duration and size of all stages obtained during the juvenile phase.

\begin{tabular}{|c|c|c|c|c|c|c|c|c|c|}
\hline Stage & $J_{1}$ & $\mathrm{~J}_{2}$ & $\mathrm{~J}_{3}$ & J 4 & $\mathrm{~J} 5$ & J 6 & $\mathrm{~J}_{7}$ & J 8 & J 9 \\
\hline $\mathrm{N}$ & 27 & 27 & 27 & 25 & 22 & 10 & 4 & 2 & 2 \\
\hline$\dagger$ & o & o & 2 & 3 & 12 & 6 & 2 & o & 2 \\
\hline$\% \mathrm{~S}$ & $100.0 \%$ & $100.0 \%$ & $92.6 \%$ & $81.5 \%$ & $37.0 \%$ & $14.8 \%$ & $7.4 \%$ & $7.4 \%$ & $0.0 \%$ \\
\hline $\mathrm{D}$ & 5.8 & 12.2 & 23.6 & 36.5 & 48.7 & 72.3 & 116.5 & 139.0 & - \\
\hline $\mathrm{Dm}$ & 3 & 10 & 19 & 28 & 39 & 51 & 102 & 127 & - \\
\hline $\mathrm{DM}$ & 9 & 17 & 33 & 47 & 62 & 106 & 131 & 151 & - \\
\hline CW & $2.70 \pm 0.17$ & $4.01 \pm 0.21$ & $5.54 \pm 0.31$ & $6.86 \pm 0.50$ & $8.16 \pm 0.51$ & $9.37 \pm 0.61$ & $10.73 \pm 0.55$ & $12.52 \pm 0.64$ & $14.06 \pm 0.30$ \\
\hline
\end{tabular}

$\mathrm{J}_{1}$ to $\mathrm{J}_{9}=$ First to ninth juvenile stage; $\mathrm{N}=$ number of individuals; $\dagger=$ number of deaths; $\% \mathrm{~S}=$ percentage of survivors; $\mathrm{D}=$ duration mean $($ accumulated days); $\mathrm{Dm}=$ minimal duration; $\mathrm{DM}=$ maximum duration; $\mathrm{CW}=$ carapace width $(\mathrm{mean} \pm \mathrm{SD})$.

A

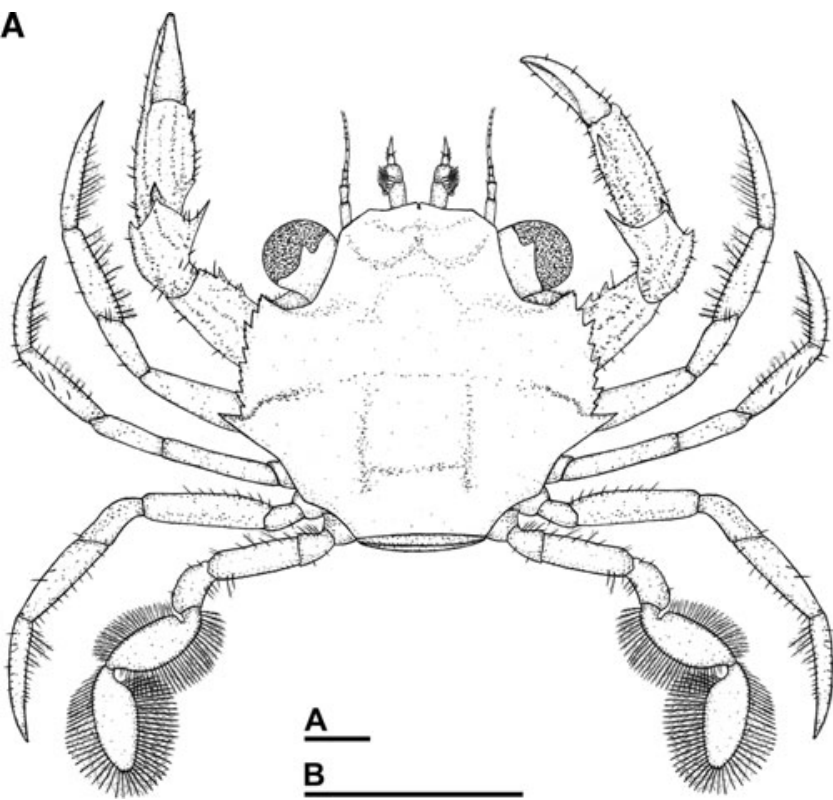

B

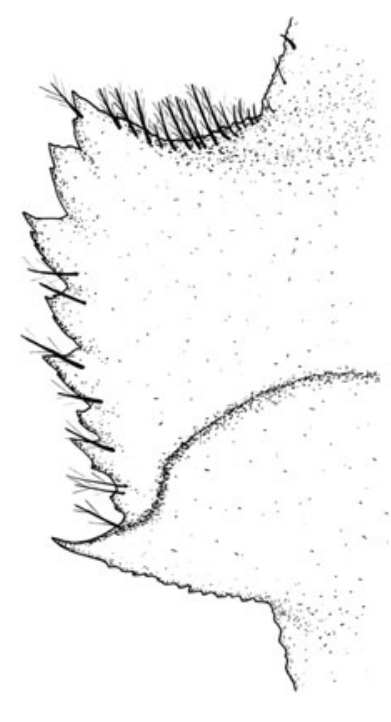

Fig. 1. Achelous spinimanus (Latreille, 1819), first juvenile stage: (A) dorsal view; (B) lateral spines of carapace in detail. Scale bars: $0.5 \mathrm{~mm}$.

Stimpson, 1860 presents three species with detailed descriptions of juvenile development. The studied species of this genus are: C. sapidus Rathbun, 1896 and C. ornatus Ordway, 1863 studied up to the 11th stage by Barutot et al. (2001) and Bolla Jr et al. (2008), respectively; and C. danae Smith, 1869 studied up to the 12th stage by Bolla Jr et al. (2014). Regarding the genus Portunus Weber, 1795, only sketchy descriptions were performed by Lebour (1944a) and Yatsuzuka \& Sakai (1980) to P. anceps (Saussure, 1858) and $P$. pelagicus (Linnaeus, 1758), respectively. For a few species of the genera Arenaeus Dana, 1851, Bathynectes Stimpson, 1871, Charybdis De Haan, 1833, Liocarcinus Stimpson, 1871, Macropipus Prestandrea, 1833, Polybius Leach, 1820 and Portumnus Leach, 1814 there are incomplete characterizations, most of them only about carapace shape. Moreover, for the genus Achelous there are no published studies concerning the juvenile development of its species as far.

The definition of peculiar characteristics of such decapods in the juvenile stages becomes a very hard task, given the scarcity of detailed descriptions about this life aspect of representatives of the superfamily Portunoidea, with occurrence in the Brazilian coast. Thus, studies based on material from laboratory rearing are fundamental for achievement of comparisons and establishment of distinctive morphological features for such species.
Recognition of the juvenile specimens of the swimming crab A. spinimanus in the natural environment is very difficult. Therefore, the aim of this study is to provide morphological details and relevant characteristics for the identification of its juvenile stages based on specimens reared in the laboratory.

\section{MATERIALS AND METHODS}

The material utilized in this study consisted, initially, of megalopae obtained from neuston samples collected at Ubatuba Bay, São Paulo state, Brazil ( $\left.23^{\circ} 26^{\prime} \mathrm{S} 46^{\circ} 09^{\prime} \mathrm{W}\right)$. This bay has a tropical/subtropical climate, whose sea surface temperature varies at around $18^{\circ} \mathrm{C}$ during winter and $29^{\circ} \mathrm{C}$ during summer (Negreiros-Fransozo \& Fransozo, 2003).

The larvae were collected by 12 nocturnal trawls of $10 \mathrm{~min}$ each, using neuston nets ( $500 \mu \mathrm{m}$ mesh), during the summer months of 2005-2007.

The megalopae of portunids have a flattened dactyl in the fifth pereiopod, similar to the adult, and have a pair of sternal spines in the seventh somite, which can provide an easy identification in the samples (Kurata, 1975). The paper by Negreiros-Fransozo et al. (2007) provided the main features that allow recognition of the megalopae of $A$. spinimanus. 

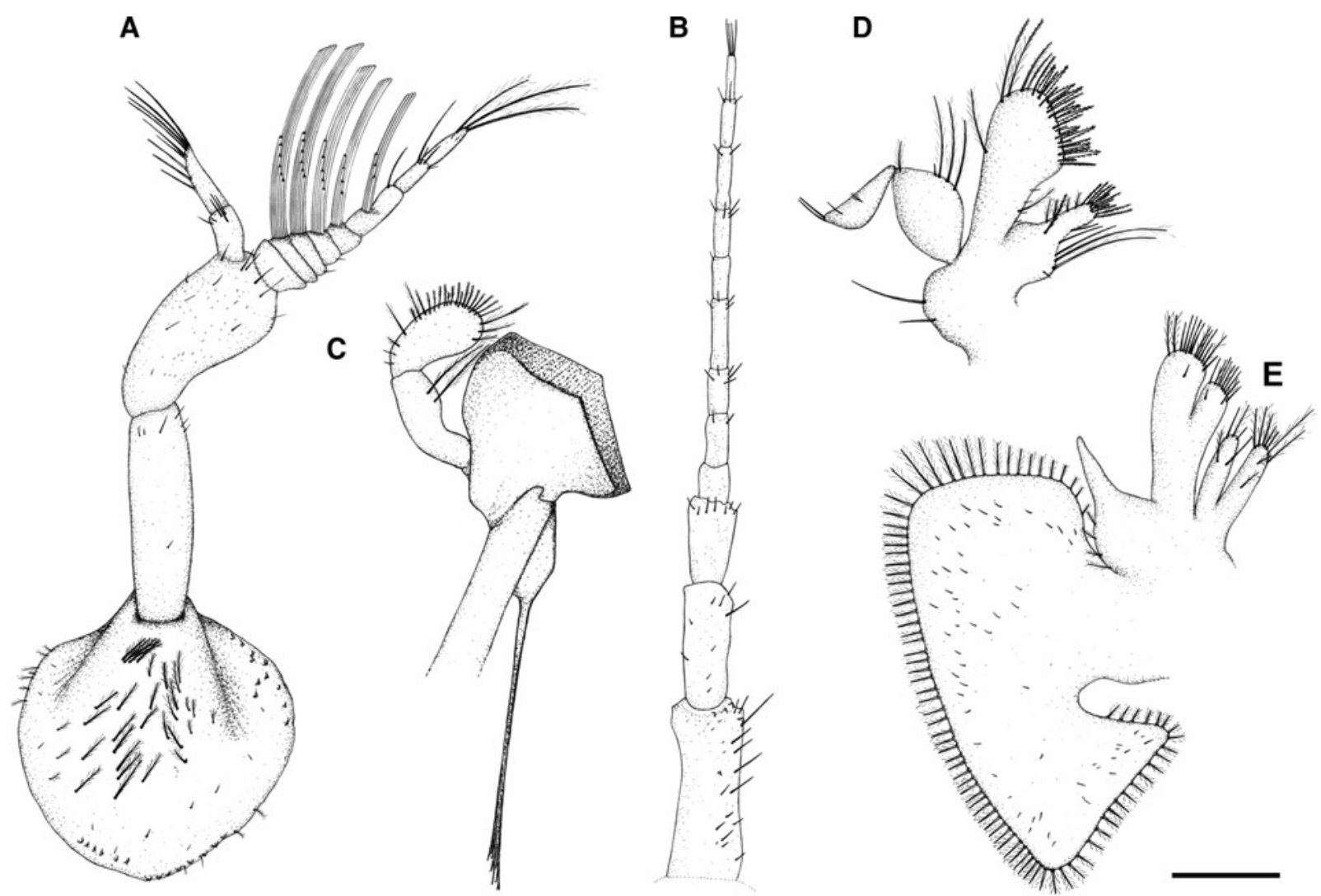

Fig. 2. Achelous spinimanus (Latreille, 1819), first juvenile stage: (A) antennule; (B) antenna; (C) mandible; (D) maxillule; (E) maxilla. Scale bar: o.2 mm.

After collection and sorting, we isolated the megalopae into covered acrylic containers $(30 \mathrm{~mL})$ filled with filtered seawater (salinity 35) from the sampling area, and transported in thermal boxes to the NEBECC laboratory.

In general, the rearing techniques adopted were similar to those used by Bolla Jr et al. (2008, 2014). The megalopae and juveniles were individually raised at $24 \pm 1{ }^{\circ} \mathrm{C}$ in containers filled with filtered and aerated seawater (salinity 35 ). We inspected the containers daily, afterwards removing all debris and exuviae or dead individuals. The water renewal in the containers occurred partially over one day, and the water was completely replaced every second day with filtered and aerated seawater. After inspection, we fed individuals with newly hatched Artemia sp. nauplii ad libitum; and we offered ornamental-fish food (Tetra Color ${ }^{\mathrm{TM}}$ Tropical Granules) for juveniles from the fifth stage on. We fixed the dead individuals and the exuviae in $80 \%$ ethanol and glycerin at $2: 1$. Part of this material was deposited in the scientific collection (number $\# 111, \#_{174}, \# 186, \#_{23} 6, \#_{463}$, \#490 and \#1772) of NEBECC, Zoology Department, Biosciences Institute, São Paulo State University, Botucatu, São Paulo, Brazil.

The stages are designated as 'juveniles' because they do not have totally mature gonads, since sexual maturity is reached, generally in portunids, with larger sizes than those obtained during the rearing (see Mantelatto \& Fransozo, 1996; Santos \& Negreiros-Fransozo, 1996; Pinheiro \& Fransozo, 1998; Corbi-Corrêa \& Fransozo, 2002).

The first juvenile stage $(\mathrm{N}=10)$ was dissected, drawn and described from fixed exuviae, using a stereoscopic microscope (Zeiss SV6) or a compound optical microscope (Zeiss
Axioskop 2), both equipped with a drawing tube and ocular micrometer. We also dissected the later stages and recorded the main morphological modifications. We based the terminology for the descriptions of setae types on Clark et al. (1998) and Garm (2004). We performed the setae observations under a microscope equipped with Nomarski optics.

\section{RESULTS}

During the rearing experiments, we obtained juvenile development until the ninth stage, when the last specimen died. Such deaths are due, probably, to the lack of a more varied diet from this phase of the species' life cycle. Table 1 presents the survival, length and size (carapace width - CW) of all stages reached. It is possible to observe that larger individuals had obtained, on average, $14 \mathrm{~mm}$ of $\mathrm{CW}$, and the highest mortality rate occurred from the fifth to sixth stage.

\section{Morphology of the first juvenile stage of A. spinimanus}

The general shape of the first stage is similar to that of the adult (Figure 1A). Carapace flattened dorso-ventrally and slightly convex, it has almost the same size in width and length, presents 8 lateral spines (finely serrated), besides the lateral pair commonly found in portunids (Figure $1 \mathrm{~B}$ ); small plumose setae on the orbital margin and small granules and 
A

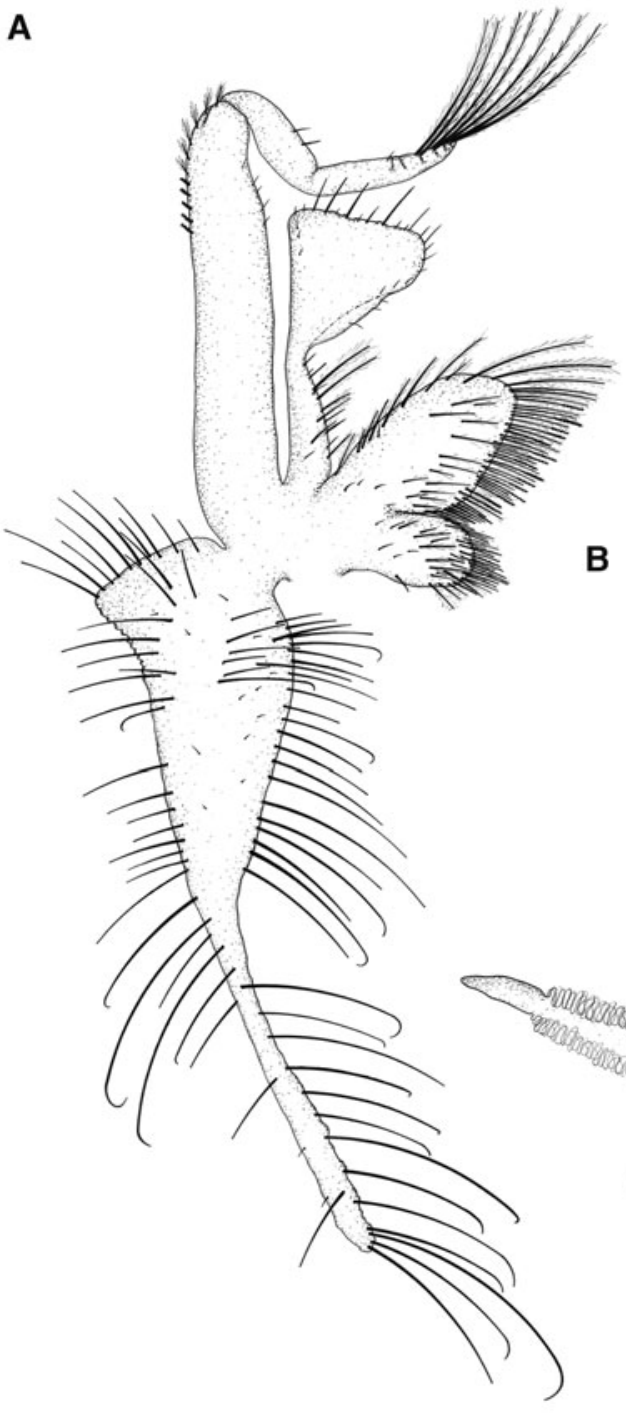

C

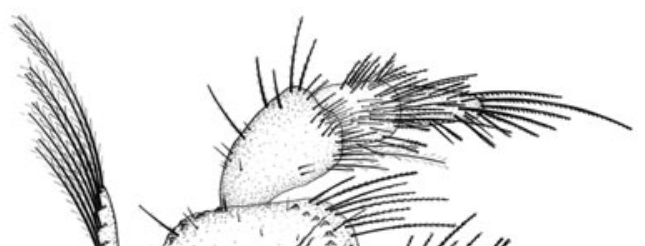

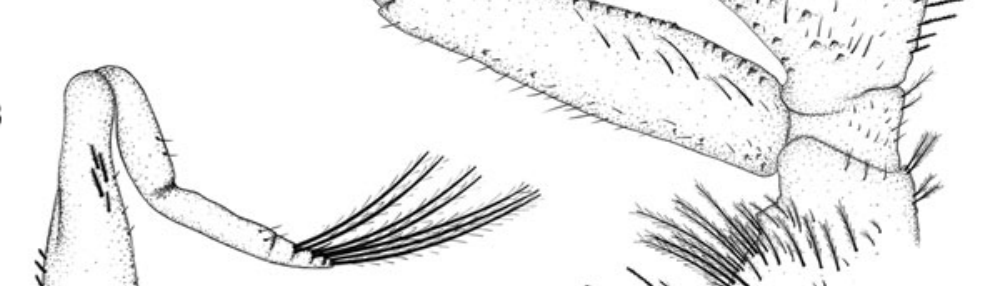

Fig. 3. Achelous spinimanus (Latreille, 1819), first juvenile stage: (A) first maxilliped; (B) second maxilliped; (C) third maxilliped. Scale bar: 0.2 mm.

sparse simple setae over the carapace surface, in addition to well-developed stalked eyes.

Antennule (Figure 2A) - developed basal segment bearing several plumose and simple setae, besides numerous small marginal granules; 2-segmented peduncle with sparse simple setae. Endopod 2-segmented (ventral flagellum) with 5 and 9 simple setae, respectively, on the proximal and distal segments. Exopod (dorsal flagellum) 8-segmented with $0,12,12,10,8,6$, o and o long aesthetascs, respectively; besides $0,0,1,1,0,1,4$ and 2 simple setae, and also 3 terminal plumose setae on the last segment.

Antenna (Figure $2 \mathrm{~B}$ ) - 3-segmented antennal peduncle, provided with sparse simple setae, besides small marginal and terminal granules on the first segment. Antennal flagellum 9-segmented with $0,2,5,4,1,4,2,3$ and 4 simple setae, all of them terminal.

Mandible (Figure 2C) - well-chitinized blade, 2-segmented palp with 2 plumose setae on proximal segment and 17 serrate setae, 5 plumose setae, 2 simple setae and 1 plumo-denticulate seta on distal segment.
Maxillule (Figure 2D) - coxal endite bearing 6 plumose setae, 4 simple setae of several sizes and 13 serrate setae; basial endite with 4 small simple setae and 1 long seta on the proximal margin, 12 serrate setae, 2 small simple, 10 cuspidate, 3 plumose and 2 plumo-denticulate setae on distal margin. The endopod is 2 -segmented with 4 plumose setae and 1 simple seta on proximal segment, and 1 plumose seta and 3 simple setae on the distal segment. Two simple setae on protopod margin.

Maxilla (Figure 2E) - bilobed coxal endite with 9 plumose setae on the proximal segment, 3 simple setae and 2 plumose setae on the distal segment; basial endite, bilobed, with 3 slightly plumose setae and 7 simple setae on the proximal segment, 2 plumose setae, 2 slightly plumose setae and 10 simple setae on the distal segment. The endopod has 4 plumose setae on distal margin. The exopod (scaphognathite) shows 86 plumose marginal setae and 57 simple surface setae.

First maxilliped (Figure 3A) - coxal endite with 19 plumose, 12 serrate and 13 simple setae; basial endite with 47 plumose setae, 17 plumo-denticulate and 4 small simple 


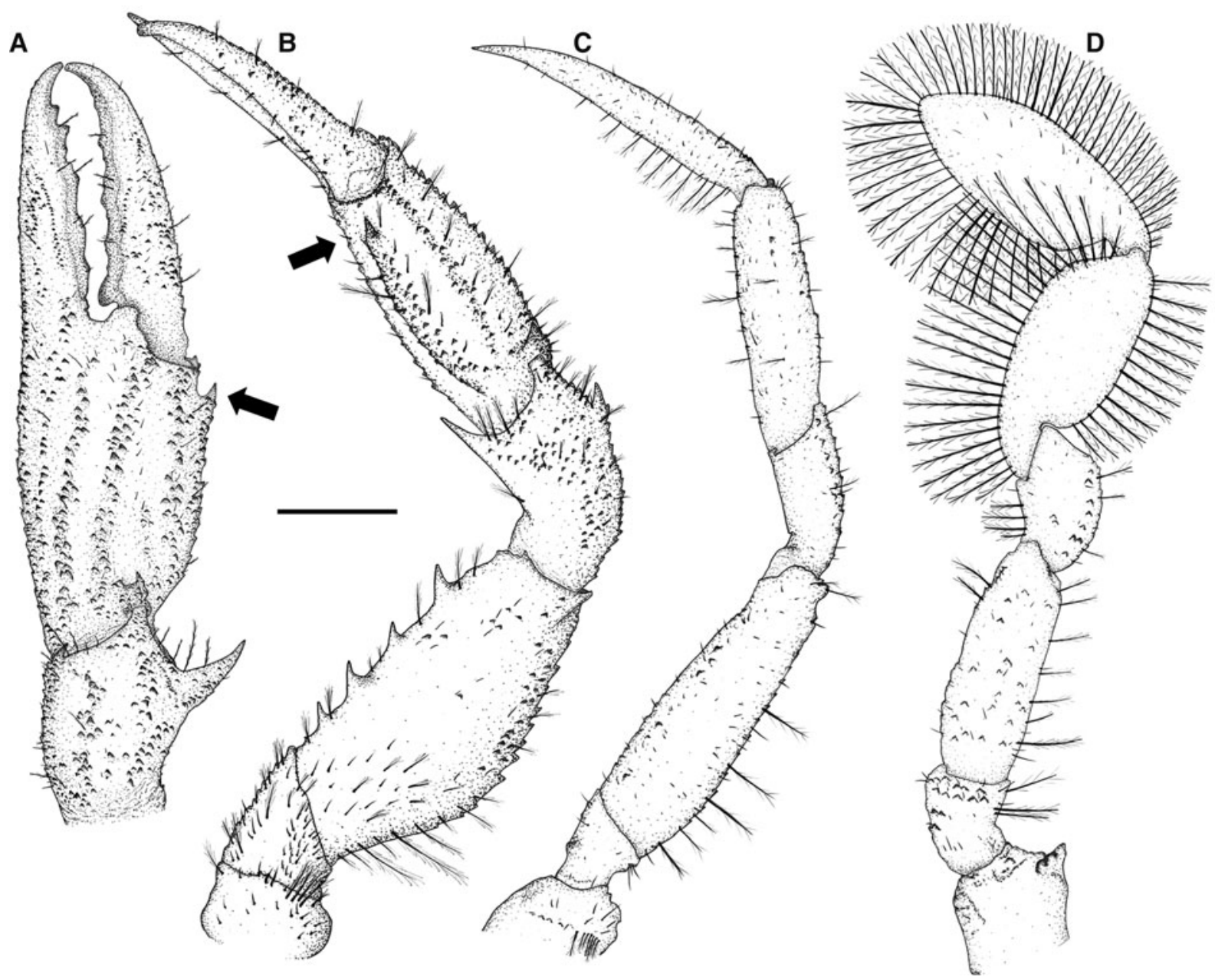

Fig. 4. Achelous spinimanus (Latreille, 1819), first juvenile stage: (A) cheliped (lateral view); (B) cheliped (dorsal view); (C) third pereiopod; (D) fifth pereiopod. Arrows indicate the propodus spine, characteristic of this species. Scale bar: $0.4 \mathrm{~mm}$.
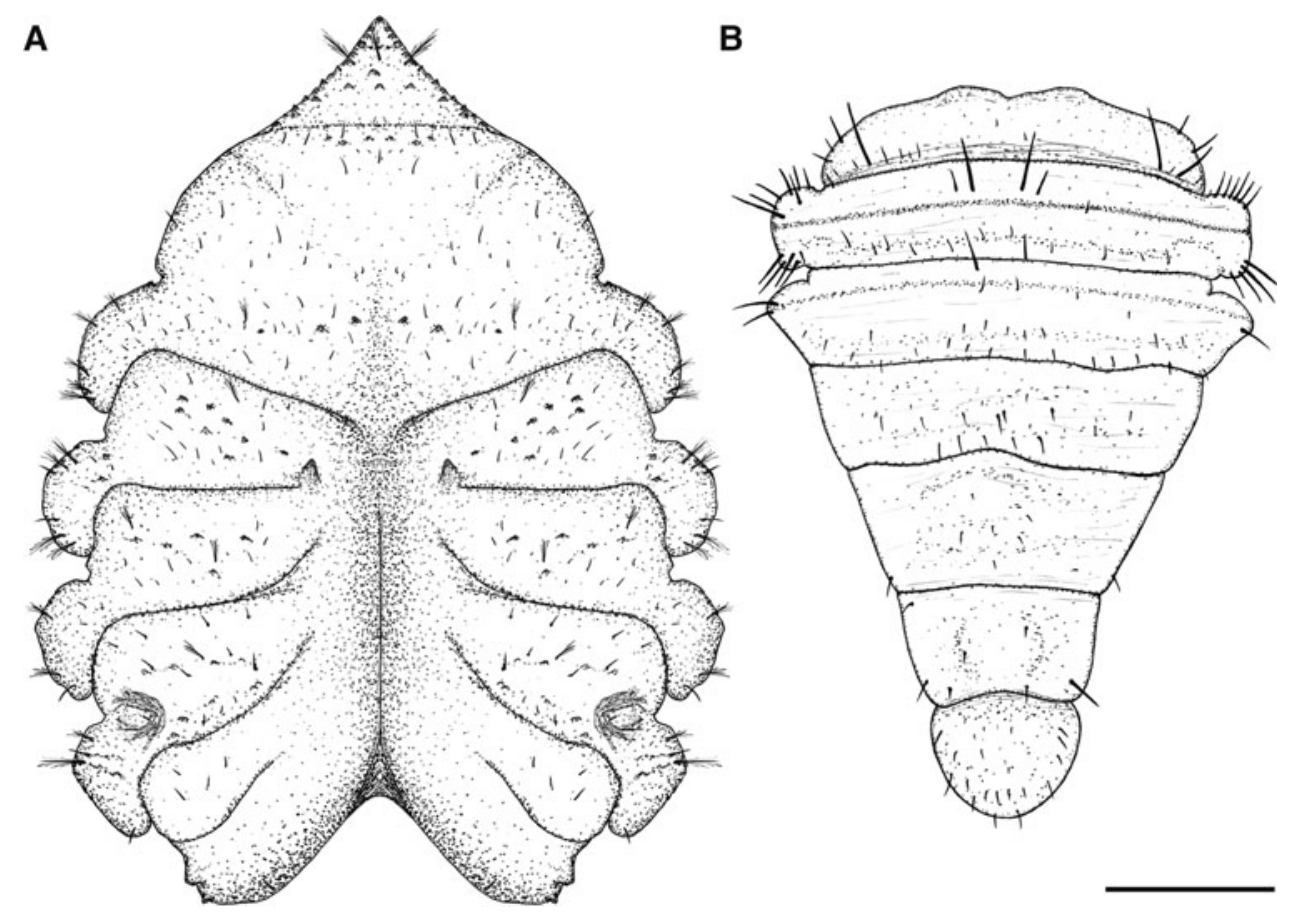

Fig. 5. Achelous spinimanus (Latreille, 1819), first juvenile stage: (A) sternum (ventral view); (B) abdomen (dorsal view). Scale bar: o.4 mm. 


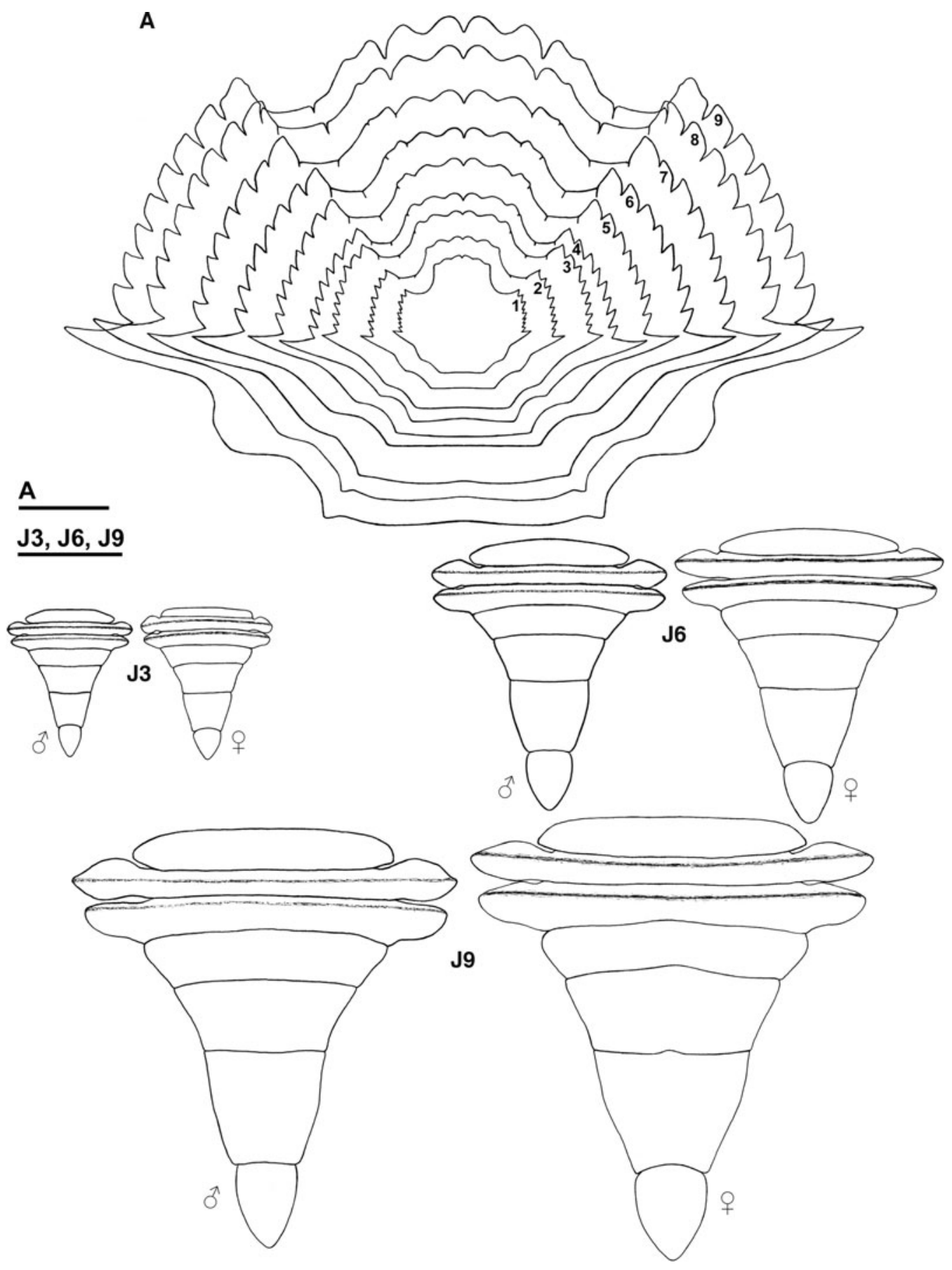

Fig. 6. Achelous spinimanus (Latreille, 1819): (A) carapace development throughout all juvenile stages obtained (numbers represent the stage of the juvenile phase); ( $\left.33-J_{6}-\mathrm{J}_{9}\right)$ development of the abdomen shape of both males and females in third, sixth and ninth stages, respectively. Scale bars: A, $2.5 \mathrm{~mm}$; 3 - J9, 2 mm.

setae. The endopod is unsegmented with 6 plumose setae and 34 simple setae of several sizes; 2-segmented exopod with 6 plumose, 5 simple and 5 cuspidate setae on the proximal segment, 7 plumose and 3 simple setae on the distal segment. The epipod is large, with 77 long simple setae and 14 small simple setae.

Second maxilliped (Figure $3 \mathrm{~B}$ ) - 5-segmented endopod with $10,17,2,7$ and 4 plumose setae, 2 and 7 serrate setae and 1 and 4 cuspidate setae on the fourth and fifth segments, respectively; 1 plumo-denticulate setae on the third and on the fourth segment, besides $0,6,3,5$ and o simple setae. The exopod is 2segmented with 14 plumose setae, 17 simple setae and 9 cuspidate setae on the proximal segment; 5 simple setae and 7 plumose setae on the distal segment. The protopod shows 7 plumose setae and 4 simple setae; and the epipod is rudimentary and smooth.

Third maxilliped (Figure ${ }_{3} \mathrm{C}$ ) - 5-segmented endopod with several protuberances on the first and second segments, several setae on each segment: $29,9,12,25,13$ serrate setae, 29, 11, 11, 6 , o plumose setae, $46,20,17,8,4$ simple setae from the proximal to distal segment. The exopod is 2-segmented with several marginal protuberances, 8 plumose setae and 41 simple setae on the proximal segment and 8 plumose and 5 simple setae on the distal. The protopod has 34 plumose setae of several sizes and 

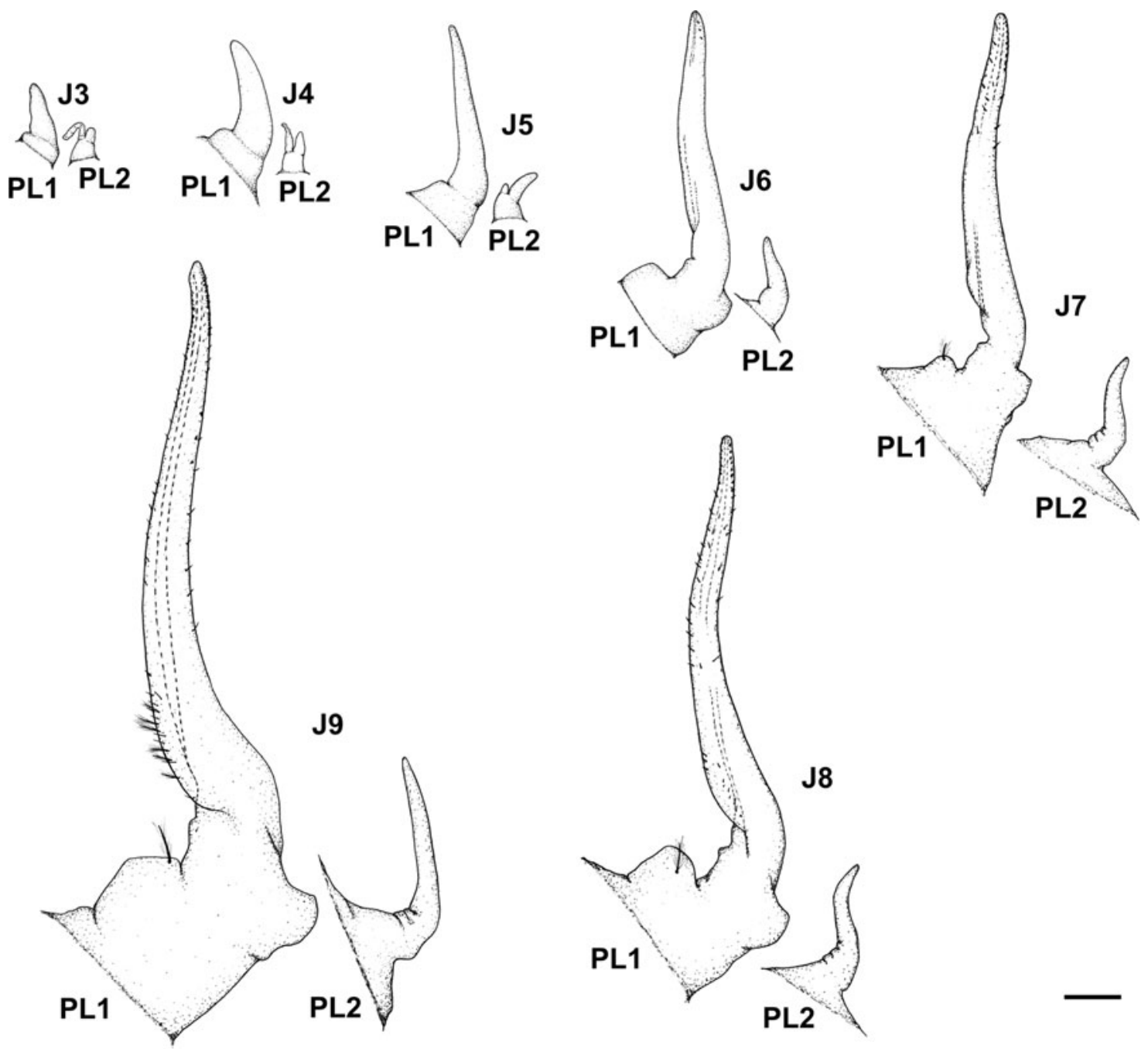

Fig. 7. Achelous spinimanus (Latreille, 1819), PL1 and PL2: pleopods of the first and second male abdominal somites, respectively, from third (J3), fourth (J4), fifth (J5), sixth (J6), seventh (J7), eighth (J8) and ninth (J9) stages on. Scale bar: $0.2 \mathrm{~mm}$.

21 small simple setae. The epipod shows 7 plumose setae, 3 plumo-denticulate setae and around 40 small simple setae on the proximal portion, 28 long simple setae and 2 long serrate setae on the distal portion.

Chelipeds (Figure 4A, B) symmetrical, with small spines on external margin and 4 strong inner ones on merus, and 3 terminal spines on carpus with the dorsal one being the longest; its propodus presents a spine (Figure 4, arrows) in the inner margin at the level of the dactyl, characteristic of this species, as well as simple and plumose setae sparsely distributed. Second, third (Figure $4 \mathrm{C}$ ) and fourth pereiopods are similar, with sparse simple and plumose setae present (the dactyls show several grouped setae on the inner margin). Fifth pair of pereiopods (Figure $4 \mathrm{D}$ ) with a spine on the coxa; both propodus and dactyls flattened; dactyls are paddleshaped with several marginal plumose setae.

Thoracic sternites (Figure $5 \mathrm{~A}$ ) with simple and plumose setae sparsely distributed over surface, concentric and semicircular wrinkles on the seventh somite (near the coxa).

Abdomen (Figure 5B) with 6 somites, each one wider than long, with several sparse simple setae; telson with small simple setae. Pleopods absent on the inner face.

\section{Morphology of the second to ninth juvenile stage of A. spinimanus}

The proportion increases between carapace width and length of the juvenile individuals in each successive ecdysis, as the individuals grow up. From the ninth stage on, the carapace reaches similar proportions to those observed in the adult phase (Figure 6A).

The abdomen increased in size during the growth time and begins to show slight changes in shape, associated with sex, from the ninth stage on. Nevertheless, such changes do not allow the visual differentiation of the sex of individuals, as can be observed in male and female adults (Figure $6 \mathrm{~J}_{3}-\mathrm{J}_{9}$ ).

The main morphological changes verified from the second juvenile stage onwards refer, mostly, to the secondary sexual characteristics. The pleopods, which were absent in the first juvenile stage, rise in different numbers and degree of development, according to each sex.

For males, in the third juvenile stage, a pair of pleopods appears on the first $\left(\mathrm{PL}_{1}\right)$ and second $\left(\mathrm{PL}_{2}\right)$ abdominal somite, respectively, being $\mathrm{PL}_{2}$ biramous (Figure $7 \mathrm{~J}_{3}$ ). In the fourth and fifth stages (Figure $7 \mathrm{~J}_{4}-\mathrm{J}_{5}$ ) there are no 

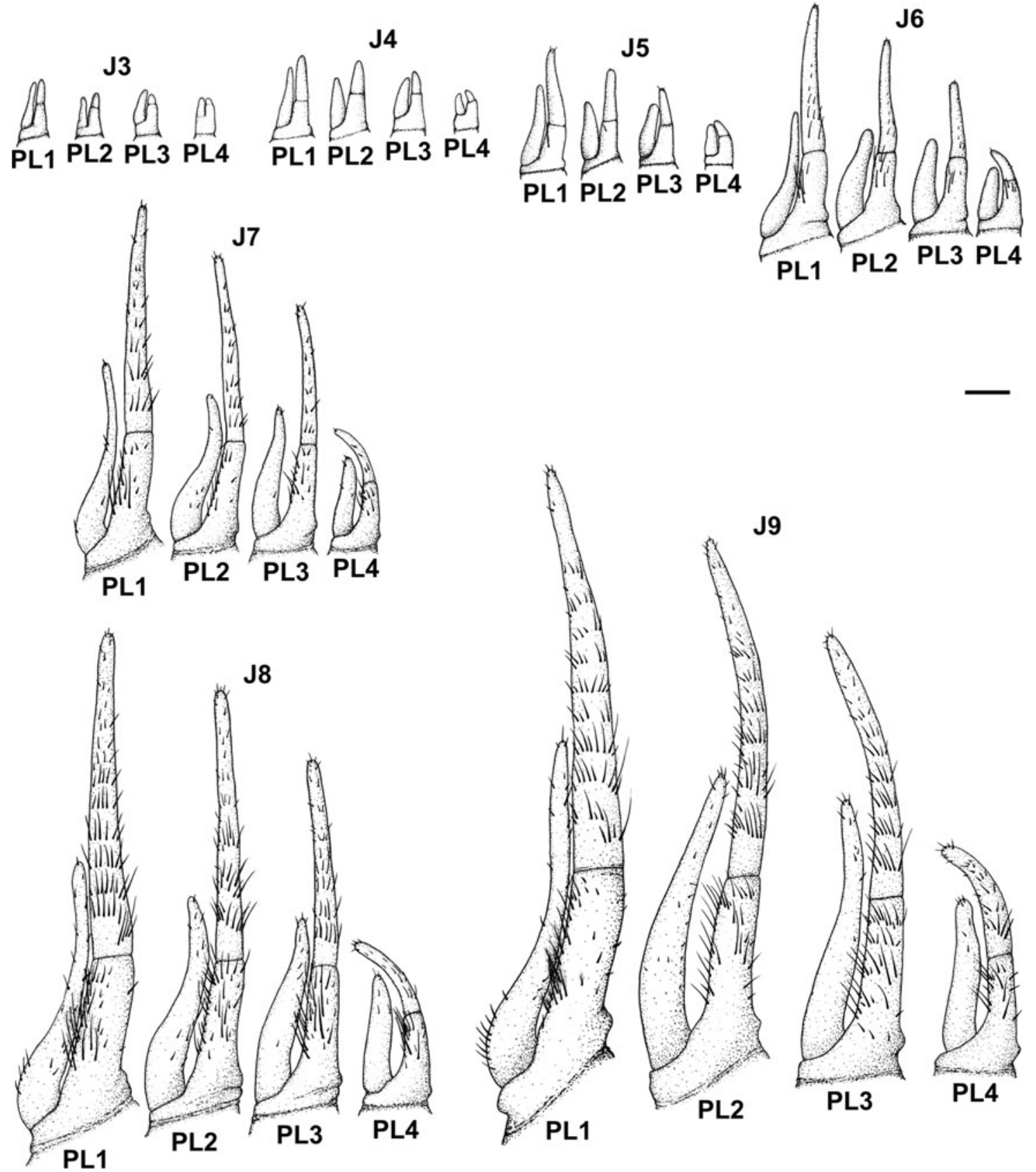

Fig. 8. Achelous spinimanus (Latreille, 1819), PL2 to PL5: pleopods from the second to fifth female abdominal somites, respectively, from third (J3), fourth (J4), fifth (J5), sixth (J6), seventh (J7), eighth (J8) and ninth (J9) stages on. Scale bar: $0.2 \mathrm{~mm}$.

significant morphological changes, with exception of increase in sizes, especially of $\mathrm{PL}_{1}$. In the sixth stage (Figure $7 \mathrm{J6}$ ) the $\mathrm{PL}_{2}$ becomes completely uniramous and a few simple setae appear on the distal portion of $\mathrm{PL}_{1}$. From the seventh to ninth stages (Figure $7 \mathrm{~J}_{7}-\mathrm{J} 9$ ) the modifications that occur on both the PL1 and PL2 are limited only to the gradual increase in size, the appearance of simple and plumose setae and emergence of some protuberances on the distal portion of $\mathrm{PL}_{1}$. In the ninth juvenile stage, the general morphology of pleopods still differs from that of adults, mainly regarding the number of setae.

For females, in the third juvenile stage 4 pairs of biramous pleopods appear from the second to fifth abdominal somite $\left(\mathrm{PL}_{2}, \mathrm{PL}_{3}, \mathrm{PL}_{4}\right.$ and $\left.\mathrm{PL}_{5}\right)$, all of them with endopods partially segmented and smooth (Figure $8 \mathrm{~J}_{3}$ ). In the fourth and fifth stages (Figure $8 \mathrm{~J}_{4}-\mathrm{J}_{5}$ ), the pleopods slightly vary in size and $\mathrm{PL}_{2}, \mathrm{PL}_{3}$ and $\mathrm{PL}_{4}$ acquire setae. In the sixth stage (Figure $8 \mathrm{J6}$ ), the endopods of the pleopods exhibit a true segmentation and increase in size and number of setae. From the seventh to ninth stages (Figure $8 \mathrm{~J} 7-\mathrm{J9}$ ), the main modifications are restricted only to the rapid increase of number of setae and size of pleopods.

We can point out some structures, which show other alterations. The most significant changes are: (1) on the endopod of the first maxilliped with a foliaceous shape and a groove in the apical region, particularly in the inner margin from the third stage on; and (2) on the first segment of the antennal peduncle, with the apical region showing a 
Table 2. Achelous spinimanus (Latreille, 1819).

\begin{tabular}{|c|c|c|c|c|c|c|c|c|c|}
\hline \multirow[b]{2}{*}{ Features } & \multicolumn{9}{|c|}{ Stages } \\
\hline & J1 & $\mathbf{J}_{2}$ & J3 & $\mathrm{J}_{4}$ & $\mathrm{~J}_{5}$ & J6 & $\mathrm{J}_{7}$ & J8 & J9 \\
\hline Number of segments on antennule endopod & 2 & 3 & 3 & 3 & 3 & $4(3)$ & 4 & 4 & 4 \\
\hline Number of segments on antennule exopod & 8 & 8 & 11 & 11 & 13 & 14 & 15 & 17 & 18 \\
\hline Number of segments of antennal flagellum & 9 & 10 & 12 & 15 & 18 & 21 & 22 & 24 & 26 \\
\hline Antenna length & 1.52 & 1.78 & 2.38 & 2.65 & 3.91 & 4.16 & 4.61 & 5.66 & 5.9 \\
\hline Number of setae on the basis of maxillule protopod & 2 & 2 & 3 & 3 & 5 & 6 & $8(7)$ & 11 & 12 \\
\hline Number of marginal setae on maxilla exopod & \pm 86 & \pm 112 & \pm 145 & \pm 159 & \pm 184 & \pm 213 & \pm 263 & \pm 304 & \pm 317 \\
\hline Length of maxilla exopod & 0.76 & 0.98 & 1.2 & 1.4 & 1.89 & 2.06 & 2.24 & 2.76 & 3.13 \\
\hline Number of apical setae on 1st maxilliped & 17 & 24 & 28 & \pm 33 & \pm 40 & \pm 46 & \pm 53 & \pm 66 & \pm 79 \\
\hline Length of basal segment of 1st maxilliped exopod & 0.78 & 0.99 & 1.22 & 1.4 & 1.86 & 1.96 & 2.19 & 2.61 & 2.98 \\
\hline Length of basal segment of 2 nd maxilliped exopod & 0.8 & 0.96 & 1.24 & 1.44 & 1.92 & 2.09 & 2.23 & 2.68 & 2.97 \\
\hline Length of basal segment of 3 rd maxilliped exopod & 0.77 & 0.95 & 1.23 & 1.42 & 1.89 & 1.95 & 2.22 & 2.67 & 2.93 \\
\hline Length of 2 nd pereiopod merus & 1.07 & 1.68 & 2.14 & 2.52 & 2.81 & 3.43 & 3.83 & 4.6 & 4.86 \\
\hline
\end{tabular}

Main morphological features that allow the identification of the first nine juvenile stages ( $\mathrm{J}_{1}$ to J9). Length measurements represent average values, in mm; numbers in parentheses indicate alternative values of low frequency; ' \pm ' indicates 'approximately'.

projection that resembles the antennal scale, in the advanced stages.

No significant morphological change occurs on the remaining body appendages. However, there is an increase in the number of setae on segments of each appendage. Denticule-serrulate setae on the epipod of the third maxilliped appear from the third juvenile stage on. Setae on the epipod of all maxillipeds from the fourth stage on are of the type denticule-serrulate or harpoon-shaped setae.

The most notable morphological characters that allow the identification of the first nine stages of the juvenile development of A. spinimanus are shown in Table 2.

Regarding female gonopores, their vestigial aperture comes from the third juvenile stage (Figure $9 \mathrm{~A}$, white arrow). In males, it was not possible to verify the emergence of the gonopores.

In both sexes, the abdomen remained sealed to sternum throughout the juvenile stages obtained. The presence of 2 pairs of 'closing mechanisms' or 'sternal buttons' on the sternum was verified. There is an anterior one (located on the fifth sternite, at the level of the distal region of the sixth abdominal somite) (Figure 9A, black arrow); and another, posterior one (located on the eighth sternite, at the level of the lateral region of the second abdominal somite)
(Figure 9B, black arrow). Such structures, together with cementing substances present in the contour of the abdomen, do not allow the extension of the abdomen before the beginning of the reproductive period.

The size of the chelipeds did not differ between sexes throughout the obtained juvenile stages.

\section{DISCUSSION}

Although the species studied here have recently changed to the resurrected genus Achelous, its early juvenile stages share morphological features with other species belonging to the genus Portunus, at least, for those species previously studied regarding their juvenile development. To better distinguish possible unique characteristics of these two genera we need to complete further studies.

Descriptions of the carapace of portunids show that, just in the first post-larval stage, $P$. anceps exhibits 8 lateral spines, as well the common pair of spines characteristic of this family (Lebour, 1944a). For P. pelagicus, besides the common features shared with $P$. anceps, Yatsuzuka \& Sakai (1980) also found a serrulate rostrum, as occurs for C. ornatus and C. danae studied by, respectively, Bolla $\mathrm{Jr}$
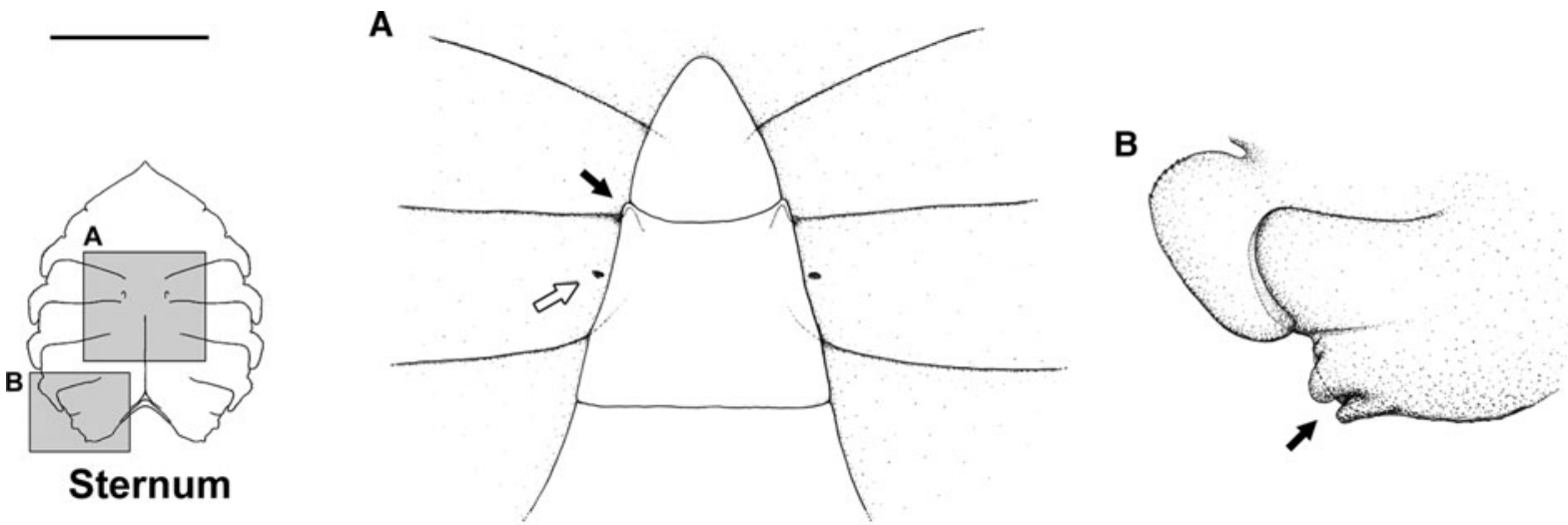

Fig. 9. Achelous spinimanus (Latreille, 1819), third juvenile stage: (A) white arrow, the rudimentary female gonopores; black arrow, anterior 'closing mechanism' position; (B) posterior 'closing mechanism' position, pointed by the black arrow (see schematic drawing of the position of the abdomen over the posterior 'closing mechanism' in Bolla Jr et al., 2014). Scale bar: $0.5 \mathrm{~mm}$. 
Table 3. List of species with some stages of the juvenile phase known to date.

\begin{tabular}{|c|c|c|c|c|}
\hline Family & Species & $\begin{array}{l}\text { Juvenile stages } \\
\text { described }\end{array}$ & $\begin{array}{l}\text { Sexual dimorphism } \\
\text { stage (based on } \\
\text { pleopods) }\end{array}$ & Reference \\
\hline Aethridae Dana, 1851 & Hepatus pudibundus & 1st to 8 th & $3 \mathrm{rd}$ & Hebling \& Rieger (2003) \\
\hline \multirow[t]{4}{*}{ Calappidae De Haan, 1833} & Calappa flammea & 1 st & $?$ & Lebour (1944a) \\
\hline & Calappa granulata & 1 st & $?$ & Guerao et al. (1998) \\
\hline & Calappa tortugae & 1st to $4^{\text {th }}$ & 2nd & Negreiros-Fransozo et al. (2007) \\
\hline & $\begin{array}{l}\text { Cryptosoma balgueri (described } \\
\text { as Cycloës bairdii) }\end{array}$ & 1st & $?$ & Lebour (1944a) \\
\hline Cancridae Latreille, 1802 & Cancer pagurus & 1 st to $3 \mathrm{rd}$ & ? & Ingle (1981) \\
\hline Dotillidae Stimpson, 1818 & Dotilla blanfordi & 1 st & $?$ & Rajabai (1959) \\
\hline Epialtidae, MacLeay, 1838 & Pisa armata & 1st & $?$ & Ingle \& Clark (1980) \\
\hline \multirow[t]{8}{*}{ Eriphiidae MacLeay, 1838} & Eriphia gonagra & 1st to 10 th & 4 th & $\begin{array}{l}\text { Fransozo \& Negreiros-Fransozo } \\
\quad(1987)\end{array}$ \\
\hline & Eurypanopeus abbreviatus & 1 st to 7 th & $4^{\text {th }}$ & $\begin{array}{l}\text { Fransozo \& Negreiros-Fransozo } \\
\quad(1987)\end{array}$ \\
\hline & Eurytium limosum & 1st to 10 th & $4^{\text {th }}$ & $\begin{array}{l}\text { Guimarães \& Negreiros-Fransozo } \\
\quad(2005)\end{array}$ \\
\hline & Hexapanopeus caribbaeus & 1 st to 11 th & $5^{\text {th }}$ & Vieira (2000) \\
\hline & Panopeus africanus & 1st & ? & Rodríguez \& Paula (1993) \\
\hline & $\begin{array}{l}\text { Panopeus austrobesus (described as } \\
\text { Panopeus herbstii) }\end{array}$ & 1 st to 15 th & $4^{\text {th }}$ & Hebling et al. (1982) \\
\hline & Panopeus occidentalis & 1st to $14^{\text {th }}$ & 6th & Rodrigues (1997) \\
\hline & Panopeus rugosus & 1 st to $14^{\text {th }}$ & 6th & Rodrigues (1997) \\
\hline Geryonidae Colosi, 1923 & $\begin{array}{l}\text { Geryon trispinosus (described as } \\
\quad \text { Geryon tridens) }\end{array}$ & 1st & $?$ & Ingle (1979) \\
\hline \multirow[t]{3}{*}{ Grapsidae MacLeay, 1838} & Pachygrapsus marmoratus & 1st & $?$ & Guerao et al. (1997) \\
\hline & Pachygrapsus transversus & 1st to 8 th & $3 \mathrm{rd}$ & Flores et al. (1998) \\
\hline & Planes minutus & 1 st & $?$ & Lebour (1944a) \\
\hline \multirow[t]{2}{*}{ Inachidae, MacLeay, 1838} & Inachus dorsettensis & 1 st & $?$ & Ingle (1977) \\
\hline & Inachus thoracicus & 1 st & $?$ & Guerao et al. (2002) \\
\hline Inachoididae Dana, 1851 & Pyromaia tuberculata & 1st to 9 th & 2nd & Flores et al. (2002) \\
\hline \multirow[t]{2}{*}{ Majidae Samouelle, 1819} & Maja brachydactyla & 1st to 8 th & $4^{\text {th }}$ & Guerao \& Rotllant (2009) \\
\hline & Maja squinado & 1st to 8 th & 4 th & Guerao \& Rotllant (2010) \\
\hline Menippidae Ortmann, 1893 & Menippe nodifrons & 1st to 8 th & $4^{\text {th }}$ & Fransozo et al. (1988) \\
\hline \multirow[t]{2}{*}{ Ocypodidae Rafinesque, 1815} & Ocypode cordimanus & 1 st & ? & Rajabai Naidu (1954) \\
\hline & Ocypode platytarsis & 1st & $?$ & Rajabai Naidu (1954) \\
\hline Panopeidae Ortmann, 1893 & $\begin{array}{l}\text { Acantholobulus bermudensis } \\
\text { (described as Panopeus } \\
\text { bermudensis) }\end{array}$ & 1 st to 14 th & 6th & Martin et al. (1984) \\
\hline Pinnotheridae De Haan, 1833 & Pinnixa rathbuni & 1 st & $?$ & Muraoka (1979) \\
\hline Percnidae Števčić, 2005 & Percnon gibbesii & 1 st & $?$ & Paula \& Hartnoll (1989) \\
\hline \multirow[t]{19}{*}{ Portunidae Rafinesque, 1815} & Arenaeus cribrarius & 1 st to $3 \mathrm{rd}$ & $?$ & Stuck \& Truesdale (1988) \\
\hline & Achelous spinimanus & 1st to 9 th & $3 \mathrm{rd}$ & Present study \\
\hline & Bathynectes longipes & 4 th? to 6 th? & $?$ & Ingle \& Rice (1984) \\
\hline & Callinectes danae & 1 st to 12 th & 4 th & Bolla Jr et al. (2014) \\
\hline & Callinectes ornatus & 1st to 11 th & $4^{\text {th }}$ & Bolla Jr et al. (2008) \\
\hline & Callinectes sapidus & 1st to 11 th & 4 th & Barutot et al. (2001) \\
\hline & Carcinus maenas & 1st to 9 th & 2nd & Shen (1935) \\
\hline & Charybdis hellerii & 1 st to $3 \mathrm{rd}$ & $?$ & Dineen et al. (2001) \\
\hline & Liocarcinus arcuatus & 1st & ? & Ingle \& Rice (1984) \\
\hline & Liocarcinus depurator & 1 st to $5^{\text {th }}$ & 2nd & $\begin{array}{l}\text { Ingle \& Rice (1984); Guerao \& } \\
\text { Abelló (2011) }\end{array}$ \\
\hline & Liocarcinus holsatus & 1 st to $3 \mathrm{rd}$ & $?$ & Ingle \& Rice (1984) \\
\hline & Liocarcinus puber & 1st to $4^{\text {th }}$ & ? & Ingle \& Rice (1984) \\
\hline & Liocarcinus pusillus & 1st to 4 th & $?$ & Ingle \& Rice (1984) \\
\hline & Macropipus tuberculatus & 4 th? to 6 th? & $?$ & Ingle \& Rice (1984) \\
\hline & Polybius henslowii & $4^{\text {th? }}$ ? & ? & Ingle \& Rice (1984) \\
\hline & Portumnus biguttatus & 1 st & $?$ & Lebour (1944b) \\
\hline & Portumnus latipes & 1 st to 5 th? & Probably before $5^{\text {th }}$ & Lebour (1944b); Paula (1988) \\
\hline & Portunus anceps & 1st & ? & Lebour (1944a) \\
\hline & Portunus pelagicus & 1 st to $3 \mathrm{rd}$ & $?$ & Yatsuzuka \& Sakai (1980) \\
\hline $\begin{array}{r}\text { Pseudorhombilidae } \\
\text { Hendrickx, } 1998\end{array}$ & Bathyrhombila sp. & 1 st to $14^{\text {th }}$ & 4 th & Moraes et al. (2011) \\
\hline
\end{tabular}


Table 3. Continued

\begin{tabular}{|c|c|c|c|c|}
\hline Family & Species & $\begin{array}{l}\text { Juvenile stages } \\
\text { described }\end{array}$ & $\begin{array}{l}\text { Sexual dimorphism } \\
\text { stage (based on } \\
\text { pleopods) }\end{array}$ & Reference \\
\hline \multirow[t]{6}{*}{ Sesarmidae Dana, 1851} & Armases ricordi & 1 st & $?$ & $\begin{array}{l}\text { Diaz \& Ewald (1968); Guerao et al. } \\
\quad(2007)\end{array}$ \\
\hline & Armases roberti & 1st & ? & Guerao et al. (2007) \\
\hline & Armases rubripes & 1st to 1 oth & 5th & $\begin{array}{l}\text { Diaz \& Ewald (1968); } \\
\text { Negreiros-Fransozo et al. } \\
\text { (2011) }\end{array}$ \\
\hline & Chiromantes eulimene & 1st & ? & Guerao et al. (2011) \\
\hline & Perisesarma fasciatum & 1 st & $?$ & Guerao et al. (2004) \\
\hline & Sesarma rectum & 1 st to $15^{\text {th }}$ & 12 th & Fransozo $(1986 / 87)$ \\
\hline \multirow[t]{2}{*}{ Ucididae Števčić, 2005} & Uca cumulanta & 1st to 8 th & 3 rd & Hirose et al. (2010) \\
\hline & Uca maracoani & 1st to 9 th & 6th to $+; 7$ th to $O^{x}$ & $\begin{array}{l}\text { Hirose \& Negreiros-Fransozo } \\
\quad(2008)\end{array}$ \\
\hline \multirow{3}{*}{$\begin{array}{l}\text { Varunidae H. Milne-Edwards, } \\
\quad 1853\end{array}$} & Cyrtograpsus angulatus & 1 st to 13 th & $4^{\text {th }}$ & Rieger \& Beltrão (2000) \\
\hline & Eriocheir japonica & 1st to 5 th & $3 \mathrm{rd}$ & Lee et al. (1994) \\
\hline & $\begin{array}{l}\text { Neohelice granulata (described as } \\
\text { Chasmagnathus granulata) }\end{array}$ & 1st to 8 th & 3 rd & Rieger \& Nakagawa (1995) \\
\hline \multirow[t]{2}{*}{ Xanthidae MacLeay, 1838} & Leptodius exaratus MacLeay, 1838 & 1st to 9 th & $4^{\text {th }}$ & Lwin et al. (2007) \\
\hline & Xantho pilipes MacLeay, 1838 & 1st & $?$ & Paula \& Dos Santos (2000) \\
\hline
\end{tabular}

'?' = the authors did not mention or did not see the stage in which the sexual differentiation occurs.

et al. (2008) and Bolla Jr et al. (2014), and for A. spinimanus (present study).

Definitions of specific morphological characteristics for each species, both portunids as well as representatives from other groups, are extremely complex due to the low number of previous studies on juvenile development among Decapoda. However, such definition is particularly crucial, as a tool for identification of juveniles of these decapods, for monitoring of areas of population growth, especially for threatened and/or invasive species.

For morphological descriptions of juvenile decapods, the authors take into account the number of segments and setae present on body appendages. Nevertheless, due to the difficulty in finding distinctive characters with light microscopy, the study of the juvenile phase has been limited to the count of setae on appendices and the mapping of its distribution throughout the body of the animal (Rieger \& Beltrão, 2000).

In this study, some appendages and morphological characteristics proved to be of great importance due to some peculiarities, which are observed with minimal manipulation of specimens and, probably, could be used for future comparisons and species identification. We can point out the following characters in this procedure: (1) the spines of internal margin of merus of the cheliped (A. spinimanus and $P$. pelagicus show 4 spines, whereas $C$. danae, C. ornatus and C. sapidus show only 3 ); (2) the long superior spine of carpus of the cheliped (present in A. spinimanus and $P$. pelagicus and absent in C. danae, $C$. ornatus and C. sapidus); and (3) the segmentation of the mandible palp (which is 2-segmented in A. spinimanus and $P$. pelagicus and 3 -segmented in $C$. danae, $C$. ornatus and $C$. sapidus). These morphological features can provide separations among the species of the genus Callinectes and the genera Portunus and Achelous, but not only between the last two genera.

Another two easy differentiations detected for each species are: (1) the number of segments on antennal flagellum (C. sapidus, A. spinimanus, C. danae and C. ornatus show 8, 9, 10 and 10(11) segments, respectively); and (2) the number of segments on the exopod of antennule - A. spinimanus is the only one among the species of these two genera that has 8 segments (other species have 7 segments), in addition to a set of aesthetascs. This feature probably could be used for quick identification, while new descriptions are not provided for the other species of this group.

Concerning the sternum, the presence of concentric and semi-circular wrinkles on the seventh somite of the first juvenile stage, observed in A. spinimanus, C. danae and C. ornatus, could be explained as a remnant of sternal spine found in the same place during the megalopa stage, and it is characteristic of this larval phase for the family Portunidae (Kurata, 1975). Additionally, such wrinkles was not found in the later stages, reinforcing this idea; however, further studies are necessary to clear up the origin of these structures. In C. sapidus and $P$. pelagicus, the authors did not report the presence of these wrinkles, probably because they did not note this feature.

The superior abdominal closing mechanism (located on the fifth thoracic sternite) of the juvenile phase of A. spinimanus, $C$. danae and C. ornatus is in accordance with the more typical system of sealing found in Eubrachyura (Guinot \& Bouchard, 1998). Nevertheless, nothing is mentioned in the literature about the inferior closing mechanism (on the eighth sternite), except for $C$. danae, in which this feature is also present (see Bolla Jr et al., 2014 for details). Thus, this mechanism could be exclusive to the family Portunidae, but we could only confirm this hypothesis with further studies of other species within and outside this family.

The sexual dimorphism in the abdomen shape of males and females adults is not evident throughout the stages obtained for A. spinimanus. For C. sapidus, C. ornatus and $P$. pelagicus studied, respectively, up to the 11 th, 12 th and third juvenile stages, the sexual dimorphism in the abdomen shape was also not observed. Thus, probably this feature appears in later stages for the Portunoidea species, in contrast to representatives of other superfamilies. For instance, in Inachus dorsettensis Pennant, 1777 (Majoidea) and Pachygrapsus transversus Gibbes, 1850 (Grapsoidea), the 


\begin{tabular}{|c|c|c|c|c|c|c|c|c|c|c|c|c|c|}
\hline \multicolumn{2}{|c|}{ 1st juvenile stage } & \multirow[t]{3}{*}{ Reference } & \multirow{2}{*}{\multicolumn{2}{|c|}{$\begin{array}{l}\text { Antennule } \\
\text { Seg }\end{array}$}} & \multirow{3}{*}{$\begin{array}{l}\text { Antenna } \\
\text { Seg }\end{array}$} & \multirow{3}{*}{$\begin{array}{l}\text { Mandible } \\
\text { Seg of } \\
\text { palp }\end{array}$} & \multicolumn{2}{|c|}{ Maxillule } & \multirow{3}{*}{$\begin{array}{l}\text { Maxilla } \\
\text { Setae on: (CE); } \\
\text { (BE); (E); (Ex) } \\
\text { (marginal) }\end{array}$} & \multicolumn{2}{|c|}{ 1st Maxilliped } & \multirow{3}{*}{$\begin{array}{l}\text { 2nd Maxilliped } \\
\text { Setae on: (E); } \\
(\text { Ex); (Ep) }\end{array}$} & \multirow{3}{*}{$\begin{array}{l}\text { 3rd Maxilliped } \\
\text { Setae on: } \\
\text { (P); (Ex); (Ep) }\end{array}$} \\
\hline \multirow[t]{2}{*}{ Family } & \multirow[t]{2}{*}{ Species } & & & & & & \multirow{2}{*}{$\begin{array}{l}\text { Seg } \\
\text { of } \\
(\mathrm{E})\end{array}$} & \multirow{2}{*}{$\begin{array}{l}\text { Setae on: (P); } \\
\text { (CE); (BE); (E) }\end{array}$} & & \multirow{2}{*}{$\begin{array}{l}\text { Seg } \\
\text { of } \\
(\mathrm{E})\end{array}$} & \multirow{2}{*}{$\begin{array}{l}\text { Setae on: (CE); } \\
(\mathrm{BE}) ;(\mathrm{E}) \text {; (Ex); } \\
(\mathrm{Ep})\end{array}$} & & \\
\hline & & & (E) & $(E x)$ & & & & & & & & & \\
\hline Aethridae & $\begin{array}{l}\text { Hepatus } \\
\quad \text { pudibundus }\end{array}$ & $\begin{array}{l}\text { Hebling \& } \\
\quad \text { Rieger (2003) }\end{array}$ & 2 & 8 & $3+7-8$ & 2 & 1 & $\begin{array}{l}\text { 4(P); } 15-17(\mathrm{CE}) \\
23-25(\mathrm{BE}) \\
6(\mathrm{E})\end{array}$ & $\begin{array}{l}10-12+6- \\
8(\mathrm{CE}) ; 8-9+ \\
7-10(\mathrm{BE}) ; 8- \\
10(\mathrm{E}) ; 73- \\
93(\mathrm{Ex})\end{array}$ & 1 & $\begin{array}{c}20-22(\mathrm{CE}) ; 32- \\
35(\mathrm{BE}) ; 29- \\
30(\mathrm{E}) ; 7-9,2- \\
3(\mathrm{Ex}) ; 24(\mathrm{Ep})\end{array}$ & $\begin{array}{l}\text { 10,4,6,4(E); } \pm 17,4- \\
\text { 7(Ex); } 13(\mathrm{Ep})\end{array}$ & $\begin{array}{l} \pm 26(\mathrm{P}) ; 12,0- \\
3(\mathrm{Ex}) ; 26(\mathrm{Ep})\end{array}$ \\
\hline \multirow[t]{7}{*}{ Eriphiidae } & Eriphia gonagra & $\begin{array}{l}\text { Fransozo \& } \\
\quad \text { Negreiros- } \\
\text { Fransozo } \\
(1987)\end{array}$ & 3 & 6 & $4+8$ & 2 & 2 & $\begin{array}{c}3(\mathrm{P}) ; 21-22(\mathrm{CE}) \\
27-32(\mathrm{BE}) \\
7-9,8-9(\mathrm{E})\end{array}$ & $\begin{array}{c}18-20+9- \\
13(\mathrm{CE}) ; 12- \\
15+16- \\
18(\mathrm{BE}) ; 8(\mathrm{E}) \\
90-95(\mathrm{Ex})\end{array}$ & 2 & $\begin{array}{c}9-11(\mathrm{CE}) ; 24- \\
27(\mathrm{BE}) ; 16- \\
18,15-17(\mathrm{E}) \\
19,2+8(\mathrm{Ex}) \\
6-7+27- \\
30(\mathrm{Ep})\end{array}$ & $\begin{array}{c}\mathrm{Nu}(\mathrm{E}) ; 27-29,3+ \\
8(\mathrm{Ex}) ; 11-14+ \\
17-20(\mathrm{Ep})\end{array}$ & $\begin{array}{c}28-31(\mathrm{P}) ; 14- \\
15,1+9(\mathrm{Ex}) \\
35-38(\mathrm{Ep})\end{array}$ \\
\hline & $\begin{array}{r}\text { Eurypanopeus } \\
\text { abbreviatus }\end{array}$ & $\begin{array}{l}\text { Fransozo \& } \\
\quad \text { Negreiros- } \\
\quad \text { Fransozo } \\
\quad(1987)\end{array}$ & 2 & 3 & $4+7$ & 3 & 1 & $\begin{array}{l}2(\mathrm{P}) ; 14(\mathrm{CE}) \\
\quad \pm 22(\mathrm{BE}) \\
\quad 4(\mathrm{E})\end{array}$ & $\begin{array}{c}6+5(\mathrm{CE}) ; 6+ \\
\quad 7(\mathrm{BE}) ; 5-6(\mathrm{E}) \\
50-55(\mathrm{Ex})\end{array}$ & 1 & $\begin{array}{l}18-20(\mathrm{CE}) \\
29(\mathrm{BE}) ; 3+ \\
7(\mathrm{E}) ; 1,5(\mathrm{Ex}) \\
\text { 18(Ep) }\end{array}$ & $\begin{array}{l}\mathrm{Nu}(\mathrm{E}) ; 6-8,5(\mathrm{Ex}) \\
\quad 3(\mathrm{Ep})\end{array}$ & $\begin{array}{l}25-27(\mathrm{P}) ; 7,2+ \\
6(\mathrm{Ex}) ; 9+20- \\
21(\mathrm{Ep})\end{array}$ \\
\hline & $\begin{array}{l}\text { Eurytium } \\
\quad \text { limosum }\end{array}$ & $\begin{array}{l}\text { Guimarães \& } \\
\quad \text { Negreiros- } \\
\text { Fransozo } \\
(2005)\end{array}$ & 2 & 5 & $3+7$ & 2 & 1 & $\begin{array}{l}3(\mathrm{P}) ; 14(\mathrm{CE}) \\
\quad 22(\mathrm{BE}) ; 3(\mathrm{E})\end{array}$ & $\begin{array}{c}4+6(\mathrm{CE}) ; 7+ \\
9(\mathrm{BE}) ; 1(\mathrm{E}) ; \\
49-56(\mathrm{Ex})\end{array}$ & 1 & $\begin{array}{l}11(\mathrm{CE}) ; 25(\mathrm{BE}) \\
\quad 8-9(\mathrm{E}) \\
2,6(\mathrm{Ex}) \\
15(\mathrm{Ep})\end{array}$ & $\begin{array}{l}\text { 9,1,6,10(E); 10,5(Ex); } \\
\quad 2(\mathrm{Ep})\end{array}$ & $\begin{array}{l}\text { 36(P); 5,6(Ex); } \\
28(\mathrm{Ep})\end{array}$ \\
\hline & $\begin{array}{c}\text { Hexapanopeus } \\
\text { caribbaeus }\end{array}$ & Vieira (2000) & 2 & 5 & $3+6$ & 2 & 2 & $\begin{array}{l}\text { 2(P); 12-14(CE); } \\
\quad \text { 19-23(BE); } \\
\quad 3,2(\mathrm{E})\end{array}$ & $\begin{array}{c}2-3+3-4(\mathrm{CE}) \\
5-6+7- \\
8(\mathrm{BE}) ; 6(\mathrm{E}) \\
54-56(\mathrm{Ex})\end{array}$ & 1 & $\begin{array}{c}\text { 14-22(CE); 25- } \\
\text { 28(BE);8(E); } \\
\text { 0,5(Ex);2+ } \\
13-15(\mathrm{Ep})\end{array}$ & $\begin{array}{l}6,1-2,5,9(\mathrm{E}) ; 6,5(\mathrm{Ex}) \\
\quad 4-5(\mathrm{Ep})\end{array}$ & $\begin{array}{l}17-19(\mathrm{P}) ; 6- \\
7,5(\mathrm{Ex}) ; 11- \\
16+18-20(\mathrm{Ep})\end{array}$ \\
\hline & $\begin{array}{l}\text { Panopeus } \\
\quad \text { austrobesus }\end{array}$ & $\begin{array}{l}\text { Hebling et al. } \\
\quad(1982)\end{array}$ & 2 & 4 & $3+7$ & 2 & 2 & $\begin{array}{l}1(\mathrm{P}) ; 10-11(\mathrm{CE}) ; \\
\quad 15-17(\mathrm{BE}) \\
2,2(\mathrm{E})\end{array}$ & $\begin{array}{c}4+5(\mathrm{CE}) ; 5- \\
6+7(\mathrm{BE}) \\
1(\mathrm{E}) ; 50- \\
53(\mathrm{Ex})\end{array}$ & 1 & $\begin{array}{l}\text { 10(CE); 16- } \\
\quad \text { 18(BE); } 8(\mathrm{E}) ; \\
\text { 2,6(Ex); } 2+ \\
\text { 13(Ep) }\end{array}$ & $\begin{array}{l}6-8,2,6,11-13(\mathrm{E}) \\
\quad 11-12,5(\mathrm{Ex}) ; 2+ \\
\text { 5-6(Ep) }\end{array}$ & $\begin{array}{r}22-24(\mathrm{P}) ; 6,6(\mathrm{Ex}) \\
10+10-11(\mathrm{Ep})\end{array}$ \\
\hline & $\begin{array}{l}\text { Panopeus } \\
\quad \text { occidentalis }\end{array}$ & $\begin{array}{c}\text { Rodrigues } \\
\quad(1997)\end{array}$ & 2 & 6 & $3+8$ & 3 & 2 & $\begin{array}{l}4(\mathrm{P}) ; 13(\mathrm{CE}) \\
\quad 24(\mathrm{BE}) ; 2,2(\mathrm{E})\end{array}$ & $\begin{array}{c}4+7(\mathrm{CE}) ; 12+ \\
\quad 6(\mathrm{BE}) ; 6(\mathrm{E}) \\
47(\mathrm{Ex})\end{array}$ & 1 & $\begin{array}{l}\text { 17(CE); 43(BE); } \\
\text { 12(E); 4,6(Ex); } \\
\text { 17(Ep) }\end{array}$ & $\begin{array}{l}\text { 1,7,2,8,11(E); } \\
\quad \text { 12,5(Ex); } 11(\mathrm{Ep})\end{array}$ & $\begin{array}{c} \pm 37(\mathrm{P}) ; 6,8(\mathrm{Ex}) \\
8+ \pm 15(\mathrm{Ep})\end{array}$ \\
\hline & $\begin{array}{l}\text { Panopeus } \\
\text { rugosus }\end{array}$ & $\begin{array}{c}\text { Rodrigues } \\
\quad(1997)\end{array}$ & 2 & 6 & $3+7$ & 2 & 2 & $\begin{array}{l}3(\mathrm{P}) ; 15(\mathrm{CE}) \\
\quad 24(\mathrm{BE}) ; 1- \\
\quad 2,2(\mathrm{E})\end{array}$ & $\begin{array}{c}5+9(\mathrm{CE}) ; 8+ \\
12(\mathrm{BE}) ; 5(\mathrm{E}) \\
48-53(\mathrm{Ex})\end{array}$ & 1 & $\begin{array}{l}17(\mathrm{CE}) ; 35- \\
38(\mathrm{BE}) ; 11- \\
\text { 12(E); } 2- \\
3,6(\mathrm{Ex}) ; \\
18(\mathrm{Ep})\end{array}$ & $\begin{array}{c}8-10,1,8,11(\mathrm{E}) ; 10- \\
13,6(\mathrm{Ex}) ; 7(\mathrm{Ep})\end{array}$ & $\begin{array}{r}39-49(\mathrm{P}) ; 7,9(\mathrm{Ex}) \\
15+21-24(\mathrm{Ep})\end{array}$ \\
\hline Grapsidae & $\begin{array}{l}\text { Pachygrapsus } \\
\text { transversus }\end{array}$ & $\begin{array}{l}\text { Flores et al. } \\
\quad(1998)\end{array}$ & 3 & 6 & $3+8$ & 3 & 2 & $\begin{array}{l}\text { ?(P); 34(CE); } \\
\quad 35(\mathrm{BE}) ; 5,6(\mathrm{E})\end{array}$ & $\begin{array}{c}22-25+9(\mathrm{CE}) \\
11+18- \\
20(\mathrm{BE}) ; \mathrm{o}(\mathrm{E}) \\
\pm 120(\mathrm{Ex})\end{array}$ & 2 & $\begin{array}{l}\mathrm{Nu}(\mathrm{CE}) ; \mathrm{Nu}(\mathrm{BE}) ; \\
\mathrm{Nu}, 10+ \\
\text { 10(E); } 5,6(\mathrm{Ex}) ; \\
68-73(\mathrm{Ep})\end{array}$ & $\begin{array}{c}4,2, \pm 12+4,4,14- \\
16, \mathrm{Nu}(\mathrm{E}) ; 16-19+ \\
11,9(\mathrm{Ex}) ; 25(\mathrm{Ep})\end{array}$ & $\begin{array}{c}\mathrm{Nu}(\mathrm{P}) ; 17,3+ \\
6(\mathrm{Ex}) ; \mathrm{Nu}+ \\
50-55(\mathrm{Ep})\end{array}$ \\
\hline
\end{tabular}




\begin{tabular}{|c|c|c|c|c|c|c|c|c|c|c|c|c|c|}
\hline Menippidae & $\begin{array}{l}\text { Menippe } \\
\quad \text { nodifrons }\end{array}$ & $\begin{array}{l}\text { Fransozo et al. } \\
\quad(1988)\end{array}$ & 2 & 8 & $3+9$ & 2 & 2 & $\begin{array}{l}\text { 2(P); 21(CE); } \\
\quad 33(\mathrm{BE}) ; 2,3(\mathrm{E})\end{array}$ & $\begin{array}{c}5-6+7-8(\mathrm{CE}) \\
11+15- \\
17(\mathrm{BE}) ; 5(\mathrm{E}) \\
77-78(\mathrm{Ex})\end{array}$ & 1 & $\begin{array}{l}\text { 25(CE); 45(BE); } \\
\text { 17(E); } \\
\text { 13,6(Ex); } \\
\text { 土59(Ep) }\end{array}$ & $\begin{array}{l}\text { 15,6,9,14(E); 16,6(Ex); } \\
\quad 10-13(\mathrm{Ep})\end{array}$ & $\begin{array}{l} \pm 53(\mathrm{P}) ; 12,8(\mathrm{Ex}) \\
\quad 24(\mathrm{Ep})\end{array}$ \\
\hline Panopeidae & $\begin{array}{r}\text { Acantholobulus } \\
\text { bermudensis }\end{array}$ & $\begin{array}{l}\text { Martin et al. } \\
\quad(1984)\end{array}$ & ? & $?$ & ? & 2 & 2 & $\begin{array}{l}1(\mathrm{P}) ; 14-15(\mathrm{CE}) ; \\
23-24(\mathrm{BE}) \\
2-3,2(\mathrm{E})\end{array}$ & $\begin{array}{c}3+5(\mathrm{CE}) ; 7+ \\
9(\mathrm{BE}) ; 1-2(\mathrm{E}) \\
43-47(\mathrm{Ex})\end{array}$ & 1 & $\begin{array}{l}13-14(\mathrm{CE}) ; 23- \\
24(\mathrm{BE}) ; 8- \\
11(\mathrm{E}) ; 2,5- \\
6(\mathrm{Ex}) ; 15- \\
18(\mathrm{Ep})\end{array}$ & $\begin{array}{l}\text { 3,1,7,11(E); 7-11,5- } \\
\text { 6(Ex); } 3-4+2- \\
\text { 4(Ep) }\end{array}$ & $\begin{array}{c} \pm 25(\mathrm{P}) ; 4-6,5- \\
6(\mathrm{Ex}) ; 7-8+ \\
12-15(\mathrm{Ep})\end{array}$ \\
\hline Percnidae & Percnon gibbesi & $\begin{array}{l}\text { Paula \& } \\
\quad \text { Hartnoll } \\
\text { (1989) }\end{array}$ & $?$ & $?$ & $3+10$ & $?$ & $?$ & $?$ & $?$ & $?$ & $?$ & $?$ & $?$ \\
\hline \multirow[t]{4}{*}{ Portunidae } & $\begin{array}{l}\text { Achelous } \\
\quad \text { spinimanus }\end{array}$ & Present study & 2 & 8 & $3+9$ & 2 & 2 & $\begin{array}{l}\text { 2(P); 23(CE); } \\
\quad 34(\mathrm{BE}) ; 5,4(\mathrm{E})\end{array}$ & $\begin{array}{c}9+5(\mathrm{CE}) ; 10+ \\
\text { 14(BE); } 4(\mathrm{E}) \\
86(\mathrm{Ex})\end{array}$ & 1 & $\begin{array}{l}\text { 44(CE); 68(BE); } \\
\text { 40(E); } \\
\text { 16,10(Ex); } \\
91(\mathrm{Ep})\end{array}$ & $\begin{array}{l}\text { 10,23,6,16,15(E); } \\
\text { 40,12(Ex); o(Ep) }\end{array}$ & $\begin{array}{l}55(\mathrm{P}) ; 49,13(\mathrm{Ex}) \\
\quad \pm 50+30(\mathrm{Ep})\end{array}$ \\
\hline & $\begin{array}{c}\text { Callinectes } \\
\text { danae }\end{array}$ & $\begin{array}{l}\text { Bolla et al. } \\
\quad(2014)\end{array}$ & 2 & 7 & $3+10$ & 3 & 2 & $\begin{array}{l}\text { 2(P); 19(CE); } \\
\quad 30(\mathrm{BE}) ; 4,5(\mathrm{E})\end{array}$ & $\begin{array}{c}7+8(\mathrm{CE}) ; 10+ \\
\quad 16(\mathrm{BE}) ; 5(\mathrm{E}) \\
\quad 85(\mathrm{Ex})\end{array}$ & 1 & $\begin{array}{c}33(\mathrm{CE}) ; 58(\mathrm{BE}) \\
12+24(\mathrm{E}) \\
\text { 20,12(Ex); } \\
58(\mathrm{Ep})\end{array}$ & $\begin{array}{l}\text { 11,24,6,15,14(E); } \\
\text { 35,9(Ex); } 3(\mathrm{Ep})\end{array}$ & $\begin{array}{r}66(\mathrm{P}) ; 69,10(\mathrm{Ex}) \\
\pm 53+15(\mathrm{Ep})\end{array}$ \\
\hline & $\begin{array}{r}\text { Callinectes } \\
\text { ornatus }\end{array}$ & $\begin{array}{l}\text { Bolla et al. } \\
\quad(2008)\end{array}$ & 2 & 7 & $\begin{array}{c}3+10- \\
11\end{array}$ & 3 & 2 & $\begin{array}{l}3(\mathrm{P}) ; 2 \mathrm{O}(\mathrm{CE}) \\
\quad 27(\mathrm{BE}) ; 3,4- \\
5(\mathrm{E})\end{array}$ & $\begin{array}{c}6-7+7(\mathrm{CE}) ; 8- \\
9+13- \\
14(\mathrm{BE}) ; 3- \\
4(\mathrm{E}) ; 88- \\
90(\mathrm{Ex})\end{array}$ & 1 & $\begin{array}{l} \pm 26(\mathrm{CE}) \\
\pm 67(\mathrm{BE}) \\
32-35(\mathrm{E}) \\
18,11(\mathrm{Ex}) \\
\pm 49(\mathrm{Ep})\end{array}$ & $\begin{array}{l}\text { 27,8,14,14(E); } \\
\quad \text { 42,10(Ex); 6(Ep) }\end{array}$ & 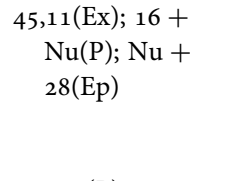 \\
\hline & $\begin{array}{r}\text { Callinectes } \\
\text { sapidus }\end{array}$ & $\begin{array}{l}\text { Barutot et al. } \\
\quad(2001)\end{array}$ & 2 & 7 & $3+8$ & 3 & 2 & $\begin{array}{l}2(\mathrm{P}) ; 15-17(\mathrm{CE}) \\
23-25(\mathrm{BE}) \\
\quad 4,2(\mathrm{E})\end{array}$ & $\begin{array}{c}\text { 7-9+3-4(CE)} \\
6-7+14- \\
16(\mathrm{BE}) ; \mathrm{o}(\mathrm{E}) \\
60-7 \mathrm{O}(\mathrm{Ex})\end{array}$ & 1 & $\begin{array}{l}\text { 17-21(CE); } 38- \\
44(\mathrm{BE}) ; 17(\mathrm{E}) \\
11-13,5- \\
\text { 6(Ex); } 28+ \\
11(\mathrm{Ep})\end{array}$ & $\begin{array}{l}12,2,3,12-14(\mathrm{E}) ; 19- \\
21,6(\mathrm{Ex}) ; \mathrm{o}(\mathrm{Ep})\end{array}$ & $\begin{array}{r}14-17(\mathrm{P}) ; 13- \\
15,5(\mathrm{Ex}) ; 9- \\
11+13(\mathrm{Ep})\end{array}$ \\
\hline Pseudorhombilidae & $\begin{array}{l}\text { Bathyrhombila } \\
\text { sp. }\end{array}$ & $\begin{array}{l}\text { Moraes et al. } \\
\quad(2011)\end{array}$ & 2 & 6 & $4+7$ & 3 & 2 & $\begin{array}{l}2-3(\mathrm{P}) ; 14- \\
\quad 17(\mathrm{CE}) ; 0- \\
6+12- \\
22(\mathrm{BE}) ; 0- \\
2,2(\mathrm{E})\end{array}$ & $\begin{array}{c}4-7+5-8(\mathrm{CE}) \\
3-7+10- \\
11(\mathrm{BE}) ; 3(\mathrm{E}) \\
48-54(\mathrm{Ex})\end{array}$ & 1 & $\begin{array}{c}\text { 19-21(CE); 31- } \\
\text { 36(BE); } 2- \\
\text { 5+5-8(E); } \\
\text { o-3,6(Ex); } \\
\text { 15-20(Ep) }\end{array}$ & $\begin{array}{l}4-5,4-9,1-2,6- \\
8,10-13(\mathrm{E}) ; 7- \\
\text { 16,6(Ex);0-5 + } \\
4-7(\mathrm{Ep})\end{array}$ & $\begin{array}{c}29-43(\mathrm{P}) ; 1-14+ \\
3,0-2+4- \\
6(\mathrm{Ex}) ; 9-36+ \\
14-27(\mathrm{Ep})\end{array}$ \\
\hline \multirow[t]{3}{*}{ Sesarmidae } & $\begin{array}{l}\text { Armases } \\
\quad \text { rubripes }\end{array}$ & $\begin{array}{l}\text { Diaz \& Ewald } \\
\quad(1968)\end{array}$ & $\mathrm{ab}$ & 3 & $3+5$ & 2 & 2 & $\begin{array}{l}\text { 2(P); 11(CE); } \\
\quad \text { 17(BE); } 2,4(\mathrm{E})\end{array}$ & $\begin{array}{l}10+4(\mathrm{CE}) ; 7+ \\
\text { 6(BE); } 0(\mathrm{E}) ; \\
\text { 50(Ex) }\end{array}$ & 1 & $\begin{array}{l}\text { 12(CE); 13(BE); } \\
\text { 5(E); 1,4(Ex); } \\
3+8(\mathrm{Ep})\end{array}$ & $\begin{array}{l}\text { 2,1,5,9(E); 8,4(Ex); } \\
\quad \text { ?(Ep) }\end{array}$ & $\begin{array}{r} \pm 16(\mathrm{P}) ; 9,5(\mathrm{Ex}) \\
\pm 30+16(\mathrm{Ep})\end{array}$ \\
\hline & $\begin{array}{l}\text { Armases } \\
\quad \text { rubripes } \\
\quad \text { (redescription) }\end{array}$ & $\begin{array}{l}\text { Negreiros- } \\
\quad \text { Fransozo } \\
\text { et al. } \\
(2011)\end{array}$ & $\mathrm{ab}$ & 3 & $3+6$ & 2 & 1 & $\begin{array}{l}\text { 1(P); 10(CE); } \\
\quad \text { 18(BE); } 2(\mathrm{E})\end{array}$ & $\begin{array}{c}11+5(\mathrm{CE}) ; 5+ \\
8(\mathrm{BE}) ; \mathrm{o}(\mathrm{E}) \\
36-38(\mathrm{Ex})\end{array}$ & 1 & $\begin{array}{l}\text { 10(CE); 14(BE); } \\
\text { 5(E); o,3(Ex); } \\
\text { 12(Ep) }\end{array}$ & $\begin{array}{l}0,2,2,7-8+9-10(\mathrm{E}) \\
\quad 8-9+1,5(\mathrm{Ex}) \\
\quad \text { ?(Ep) }\end{array}$ & $\begin{array}{c}13-19(\mathrm{P}) ; 6-7,3- \\
4(\mathrm{Ex}) ; 8-10+ \\
14-18(\mathrm{Ep})\end{array}$ \\
\hline & Sesarma rectum & $\begin{array}{l}\text { Fransozo } \\
\qquad(1986 / 87)\end{array}$ & $a b$ & 2 & $3+5$ & 2 & 2 & $\begin{array}{l}1(\mathrm{P}) ; 8-10(\mathrm{CE}) \\
15-16(\mathrm{BE}) \\
1,3(\mathrm{E})\end{array}$ & $\begin{array}{c}10-11+4(\mathrm{CE}) \\
7-8+6(\mathrm{BE}) \\
\mathrm{o}(\mathrm{E}) ; 37- \\
39(\mathrm{Ex})\end{array}$ & 1 & $\begin{array}{c}8-11(\mathrm{CE}) ; 14- \\
16(\mathrm{BE}) ; 7(\mathrm{E}) \\
2,4(\mathrm{Ex}) ; 3+ \\
6(\mathrm{Ep})\end{array}$ & $\begin{array}{l}1,1,2,4-5,8-9(\mathrm{E}) ; 8- \\
\text { 9,5(Ex); ab(Ep) }\end{array}$ & $\begin{array}{l}24-28(\mathrm{P}) ; 8,5(\mathrm{Ex}) \\
7-8+14- \\
16(\mathrm{Ep})\end{array}$ \\
\hline
\end{tabular}




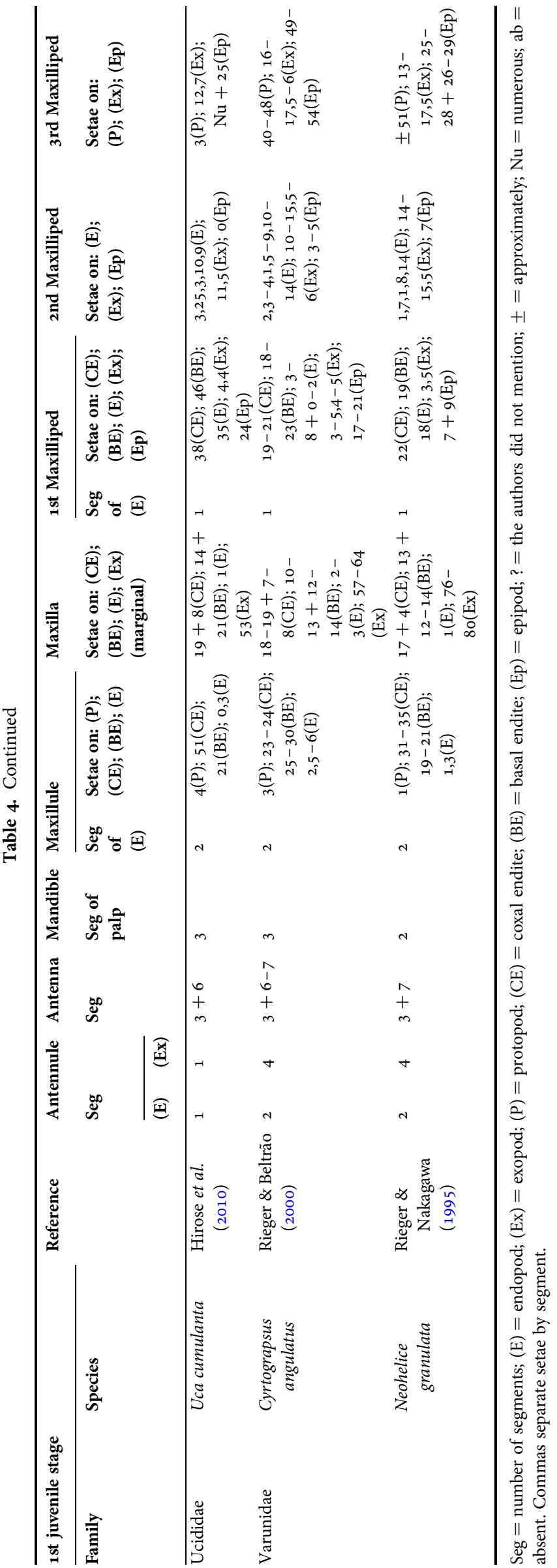

morphological sexual differentiation occurs from the third and sixth juvenile stages on, respectively (Ingle, 1977; Flores et al., 1998); in Cyrtograpsus angulatus Dana, 1851 (Grapsoidea), the sexual differentiation begins from the fourth stage on, becoming more apparent from the eighth juvenile stage on (Rieger \& Beltrão, 2000); and in Calappa tortugae Rathbun, 1933 (Calappoidea), the secondary sexual characters appear from the second juvenile stage on (Negreiros-Fransozo et al., 2007).

The presence of rudimentary pleopods in the first juvenile stage can be different among the Portunoidea species studied; this feature is present in C. sapidus, C. ornatus and P. pelagicus, but it is absent in C. sapidus and A. spinimanus. However, with the exception of $P$. pelagicus in which the rudimentary pleopods are present up to the last stage studied (third), in all other species the pleopods totally degenerate from the second juvenile stage. They reappear (two pairs for males and four pairs for females) in later juvenile stages that can vary according with species, as can be seen in Table 3. Among Portunoidea, this occurs from the third stage in A. spinimanus and from the fourth stage in C. danae, C. ornatus and C. sapidus; this, apparently, could be a particular character of these genera. Nevertheless, only with a high number of species studied of distinctive genera could one get a satisfactory definition.

Another interesting differential characteristic is the biramous condition of the second pair of the pleopods of males $\left(\mathrm{PL}_{2}\right)$, from its first appearance to the fifth stage in A. spinimanus, until the eighth stage in $C$. danae and until the sixth stage in C. ornatus. In C. sapidus, the $\mathrm{PL}_{2}$ remain biramous, at least, until the seventh stage (the authors did not report if they still are biramous in the later stages). With respect to the first pair of pleopods of males $\left(\mathrm{PL}_{1}\right)$, this is uniramous as of its origin in all Portunoidea species studied, except for $C$. sapidus, in which the $\mathrm{PL}_{1}$ is also biramous until the seventh juvenile stage. These features of pleopods, both the rudimentary ones and the biramous conditions of male pleopods, are useful for species identification within the group, since they can be easily observed.

Table 4 presents the comparative studies of the main characteristics that can be used to differentiate the species with juvenile development previously studied, and which occur in the Brazilian coast.

The description of early stages of decapod crustacean species are useful in the identification of settlement areas of such species, which is necessary to the fisheries management in many areas. In addition, it could contribute towards systematic studies, since it aids in the elaboration and validation of identification keys for adult specimens (Martin et al., 1984). Morphological studies also collaborate for effective separation of species of interest for carciniculture, besides their identification in planktonic or benthic samples (Guerao \& Abelló, 2011; Bolla Jr et al., 2014).

\section{ACKNDWLEDGEMENTS}

We thank the members of NEBECC for their assistance during this study. All sampling in this investigation was conducted in accordance with Brazilian applicable state and federal laws.

\section{FINANCIAL SUPPORT}

We are grateful to the Brazilian Council of Scientific and Technological Development (CNPq) for the first author's 
Master of Science scholarship (\#553174/2008-8) and to the São Paulo Research Foundation (FAPESP) for providing the financial support during neuston collections (\#2004/15194-6).

\section{REFERENCES}

Anger K. (2003) Salinity as a key parameter in the larval biology of decapod crustaceans. Invertebrate Reproduction and Development 43 29-45. doi: 10.1080/07924259.2003.9652520.

Barutot R.A., Vieira R.R.R. and Rieger P.J. (2001) Desenvolvimento juvenil de Callinectes sapidus Rathbun, 1896 (Crustacea: Decapoda: Portunidae), em laboratório, a partir de megalopas coletadas no plâncton. Comunicações do Museu de Ciências e Tecnologia da PUCRS, Série Zoologia 14, 23-42.

Bolla Jr E.A., Fransozo V. and Negreiros-Fransozo M.L. (2014) Juvenile development of Callinectes danae Smith, 1869 (Crustacea, Decapoda Brachyura, Portunidae) under laboratory conditions. Anais da Academia Brasileira de Ciências 86, 211-228. doi: 10.1590/ ooo1-37652014118912.

Bolla Jr E.A., Negreiros-Fransozo M.L. and Fransozo A. (2008) Juvenile development of Callinectes ornatus Ordway, 1863 (Crustacea: Decapoda: Portunidae), from megalopae obtained in the neuston Zootaxa 1788, 1-20.

Clark P.F., Calazans D.D. and Pohle G.W. (1998) Accuracy and standardization of brachyuran larval descriptions. Invertebrate Reproduction and Development 33, 127-144. doi: 10.1080/07924259.1998.9652627.

Corbi-Corrêa E. and Fransozo A. (2002) Growth patterns of Portunus spinicarpus (Stimpson, 1871) (Decapoda, Portunoidea) from Ubatuba region (SP), Brazil. Nauplius 10, 131-137.

De Grave S., Pentcheff N.D., Ahyong S.T., Chan T.Y., Crandall K.A., Dworschak P.C., Felder D.L., Feldmann R.M., Fransen C.H.J.M., Goulding L.Y.D., Lemaitre R., Low M.E.Y., Martin J.W., Ng P.K.L., Schweitzer C.E., Tan S.H., Tshudy D. and Wetzer R. (2009) A classification of living and fossil genera of decapod crustaceans. Raffles Bulletin of Zoology, Supplement 21, 1-109.

De Lestang S., Hall N. and Potter I.C. (2003) Influence of a deep artificial entrance channel on the biological characteristics of the blue swimmer crab Portunus pelagicus in a large microtidal estuary. Journal of Experimental Marine Biology and Ecology 295, 41-61. doi: 10.1016/ Soo22-0981(03)00273-9.

Demain D.K., Gallego A., Jaworski A., Priede I.G. and Jones E.G. (2011) Diet and feeding niches of juvenile Gadus morhua, Melanogrammus aeglefinus and Merlangius merlangus during the settlement transition in the northern North Sea. Journal of Fish Biology 79, 89-111. doi: 10.1111/j.1095-8649.2011.02997.x.

Diaz H. and Ewald J.J. (1968) A comparison of the larval development of Metasesarma rubripes (Rathbun) and Sesarma ricordi H. Milne Edwards (Brachyura, Grapsidae) reared under similar laboratory conditions. Crustaceana, Supplements 2, 225-248.

Dineen J.F., Clark P.F., Hines A.H., Reed S.A. and Walton H.P. (2001) Life history, larval description, and natural history of Charybdis helleri (Decapoda, Brachyura, Portunidae), an invasive crab in the Western Atlantic. Journal of Crustacean Biology 21, 774-805. doi: 10.1163/ 20021975-99990173.

Figueiredo J., Penha-Lopes G., Narciso L. and Lin J. (2008) Effect of starvation during late megalopa stage of Mithraculus forceps (Brachyura: Majidae) on larval duration, synchronism of metamorphosis, survival to juvenile, and newly metamorphosed juvenile size. Aquaculture 274, 175-180. doi: 10.1016/j.aquaculture.2007.10.052.

Flores A.A.V., Marques F.P.L. and Negreiros-Fransozo M.L. (2002) Postlarval stages and growth patterns of the spider crab Pyromaia tuberculata (Brachyura, Majidae) from laboratory-reared material. Journal of Crustacean Biology 22, 314-327. doi: 10.1163/ 20021975-99990238.

Flores A.A.V., Negreiros-Fransozo M.L. and Fransozo A. (1998) The megalopa and juvenile development of Pachygrapsus transversus (Gibbes, 1850) (Decapoda, Brachyura), compared with other grapsid crabs. Crustaceana 71, 197-222. doi: 10.1163/156854098Xoo 176 .

Fransozo A. (1986/87) Desenvolvimento dos estágios juvenis de Sesarma (Holometopus) rectum Randall, 1840 (Decapoda, Grapsidae) obtidos em laboratório. Naturalia 12, 77-87.

Fransozo A. and Negreiros-Fransozo M.L. (1987) Morfologia dos primeiros estágios juvenis de Eriphia gonagra (Fabricius, 1781) e Eurypanopeus abbreviatus (Stimpson, 1860) (Crustacea, Decapoda, Xanthidae), obtidos em laboratório. Papéis Avulsos de Zoologia 36, 257-277.

Fransozo A., Negreiros-Fransozo M.L. and Hiyodo C.M. (1988) Développement juvénile de Menippe nodifrons Stimpson, 1859 (Crustacea, Decapoda, Xanthidae) au laboratoire. Revue d'Hydrobiologie Tropicale 21, 297-308.

Garm A. (2004) Revising the definition of the crustacean seta and setal classification systems based on examinations of the mouthpart setae of seven species of decapods. Zoological Journal of the Linnean Society 142, 233-252. doi: 10.1111/j.1096-3642.2004.00132.x.

González-Gordillo J.I., Anger K. and Schubart C.D. (2010) Morphology of the larval and first juvenile stages of two Jamaican endemic crab species with abbreviated development, Sesarma windsor and Metopaulias depressus (Decapoda: Brachyura: Sesarmidae). Journal of Crustacean Biology 30, 101-121. doi: 10.1651/08-3110.1.

Guerao G. and Abelló P. (2011) Early juvenile development of Mediterranean Liocarcinus depurator (Crustacea: Decapoda: Brachyura: Portunidae). Journal of Natural History 45, 2175-2193. doi: 10.1080/00222933.2011.590948.

Guerao G., Abelló P. and Cartes J. (1998) Morphology of the megalopa and first crab instar of the Shamefaced Crab Calappa granulata (Crustacea, Brachyura, Calappidae). Miscellanea Zoologica Hungarica 21, 37-47.

Guerao G., Abelló P. and Cuesta J.A. (1997) Morphology of the megalopa and first crab stage of the mediolittoral crab Pachygrapsus marmoratus (Brachyura, Grapsidae, Grapsinae). Zoosystema 19, 437-447.

Guerao G., Anger K., Nettelmann U. and Schubart C.D. (2004) Complete larval and early juvenile development of the mangrove crab Perisesarma fasciatum (Crustacea: Brachyura: Sesarmidae) from Singapore, with a larval comparison of Parasesarma and Perisesarma. Journal of Plankton Research 26, 1389-1408. doi: 10.1093/plankt/fbh127.

Guerao G., Anger K. and Schubart C.D. (2007) Larvae and first-stage juveniles of the American genus Armases (Brachyura: Sesarmidae): a morphological description of two complete developments and one first zoeal stage. Journal of Natural History 41, 1811-1839. doi: 10.1080/00222930701500431

Guerao G. and Rotllant G. (2009) Post-larval development and sexual dimorphism of the spider crab Maja brachydactyla (Brachyura: Majidae). Scientia Marina 73, 797-808. doi: 10.3989/ scimar.2009.73n4797.

Guerao G. and Rotllant G. (2010) Development and growth of the early juveniles of the spider crab Maja squinado (Brachyura: Majoidea) in an individual culture system. Aquaculture 307, 105-110. doi: 10.1016/j.aquaculture.2010.06.006.

Guerao G., Rufino M. and Abelló P. (2002) The complete larval development and first juvenile of the spider crab Inachus thoracicus Roux, 1830 (Brachyura: Majidae: Inachinae). Journal of Plankton Ressearch 24, 875-887. doi: 10.1093/plankt/24.9.875. 
Guerao G., Simoni R., Cannicci S. and Anger K. (2011) Morphological description of the megalopa and the first juvenile crab stage of Chiromantes eulimene (Decapoda, Brachyura, Sesarmidae), with a revision on zoeal morphology. Invertebrate Reproduction and Development 55, 100-109. doi: 10.1080/07924259.2011.553416.

Guimarães F.J. and Negreiros-Fransozo M.L. (2005) Juvenile development and growth patterns in the mud crab Eurytium limosum (Say, 1818) (Decapoda, Brachyura, Xanthidae) under laboratory conditions Journal of Natural History 39, 2145-2161. doi: 10.1080/ 00222930500061254 .

Guinot D. and Bouchard J.M. (1998) Evolution of the abdominal holding systems of brachyuran crabs (Crustacea, Decapoda, Brachyura) Zoosystema 20, 613-694.

Hebling N.J., Fransozo A. and Negreiros-Fransozo M.L. (1982) Desenvolvimento dos primeiros estágios juvenis de Panopeus herbstii H. Milne-Edwards, 1834 (Crustacea, Decapoda, Xanthidae), criadas em laboratório. Naturalia 7, 177-188.

Hebling N.J. and Rieger P.J. (2003) Desenvolvimento juvenil de Hepatus pudibundus (Herbst) (Crustacea, Decapoda, Calappidae), em laboratório. Revista Brasileira de Zoologia 20, 531-539.

Hernández T.I. and Ramírez G.J. (1990) Obtención de jaiba suave Callinectes spp en flotadores de madera en Alvarado. Secretaría de Pesca, Serie Documentos de Trabajo (México) 16, 1-22.

Hirose G.L., Bolla E.A. Jr and Negreiros-Fransozo M.L. (2010) Post-larval morphology, growth, and development of Uca cumulanta Crane, 1943 (Crustacea, Decapoda, Ocypodidae) under laboratory conditions. Invertebrate Reproduction and Development 54, 95-109. doi: $10.1080 / 07924259.2010 .9652321$.

Hirose G.L. and Negreiros-Fransozo M.L. (2008) Growth and juvenile development of Uca maracoani Latreille, 1802-1803 in laboratory conditions (Crustacea, Decapoda, Brachyura, Ocypodidae). Senckenbergiana Biologica 88, 161-168.

Ingle R.W. (1977) The larval and post-larval development of the scorpion spider crab, Inachus dorsettensis (Pennant) (Family: Majidae), reared in the laboratory. Bulletin of the British Museum (Natural History), Zoology 3, 331-348.

Ingle R.W. (1979) The larval and post-larval development of the brachyuran crab Geryon tridens Kröyer (Family Geryonidae) reared in the laboratory. Bulletin of the British Museum (Natural History), Zoology 36, 217-232.

Ingle R.W. (1981) The larval and post-larval development of the Edible Crab, Cancer pagurus Linnaeus (Decapoda: Brachyura). Bulletin of the British Museum (Natural History), Zoology 40, 211-236.

Ingle R.W. and Clark P.F. (1980) The larval and post-larval development of Gibbs's spider crab, Pisa armata (Latreille) [family Majidae: subfamily Pisinae], reared in the laboratory. Journal of Natural History 14, 723-735. doi: 10.1080/00222938000770601.

Ingle R.W. and Rice A.L. (1984) The juvenile stages of eight swimming crab species (Crustacea: Brachyura: Portunidae): a comparative study. Bulletin of the British Museum (Natural History), Zoology 46, 345-354.

Kurata H. (1975) Larvae of Decapoda Brachyura of Arasaki, Sagami Bay-V. The swimming crabs of subfamily Portuninae. Bulletin of the Nansei Regional Fisheries Research Laboratory 8, 39-65.

Lebour M.V. (1944a) Larval crabs from Bermuda. Zoologica 29, 113-128.

Lebour M.V. (1944b) The larval stages of Portumnus (Crustacea, Brachyura) with notes on some other genera. Journal of the Marine Biological Association of the United Kingdom 26, 7-15. doi: 10.1017/ Soo25315400014429.

Lee T.H., Yamauchi M. and Yamazaki F. (1994) Sex differentiation in the crab Eriocheir japonicus (Decapoda, Grapsidae). Invertebrate
Reproduction and Development 25, 123-137. doi: 10.1080/ 07924259.1994.9672377.

Lwin T.T., Doi W., Yokota M., Strüssmann C.A. and Watanabe S. (2007) Juvenile morphology of the xanthid crab Leptodius exaratus (H. Milne-Edwards, 1834) (Decapoda: Brachyura), with notes on the appearance of sexual dimorphism. Invertebrate Reproduction and Development 50, 191-201. doi: 10.1080/07924259.2007.9652246.

Mantelatto F.L.M. and Fransozo A. (1996) Size at sexual maturity in Callinectes ornatus (Brachyura, Portunidae) from the Ubatuba region (SP), Brazil. Nauplius 4, 29-38.

Mantelatto F.L.M. and Fransozo A. (1999). Reproductive biology and moulting cycle of the crab Callinectes ornatus Ordway, 1863 (Decapoda, Brachyura, Portunidae) from Ubatuba region, São Paulo, Brazil. Crustaceana 72, 63-76. doi: 10.1163/156854099502871.

Mantelatto F.L.M., Robles R., Schubart C.D. and Felder D.L. (2009) Molecular phylogeny of the genus Cronius Stimpson, 1860, with reassignment of C. tumidulus and several American species of Portunus to the genus Achelous De Haan, 1833 (Brachyura: Portunidae). In Martin J.W., Crandall K.A. and Felder D.L. (eds) Crustacean issues: decapod crustacean phylogenetics. Boca Raton, FL: Taylor \& Francis/CRC Press, pp. 537-551.

Marques F.P.L., Pohle G.W. and Vrbova L. (2003) On the larval stages of Macrocoeloma diplacanthum (Decapoda: Brachyura: Majidae), and a review of Mithracine phylogenetic aspects. Journal of Crustacean Biology 23, 187-200. doi: 10.1163/20021975-99990326.

Martin J.W., Felder D.L. and Truesdale F.M. (1984) A comparative study of morphology and ontogeny in juvenile stages of four western Atlantic xanthoid crabs (Crustacea: Decapoda: Brachyura). Philosophical Transactions of the Royal Society B 303, 537-604. doi: 10.1098/rstb.1984.0001.

Melo G.A.S. (1996) Manual de Identificação dos Brachyura (Caranguejos e Siris) do Litoral Brasileiro. 1st edition. São Paulo: Plêiade/FAPESP.

Moraes J.C.B., Negreiros-Fransozo M.L. and Melo G.A.S. (2011) Juvenile development of the crab Bathyrhombila sp. (Crustacea, Decapoda, Pseudorhombilidae) from megalopae obtained in the neuston. Marine Biology Research 7, 159-175. doi: 10.1080/ 17451000.2010.489754

Muraoka K. (1979) On the post-larva of Pinnixa rathbuni Sakai (Crustacea, Brachyura, Pinnotheridae). Zoological Magazine (Tokyo) $88,288-294$.

Negreiros-Fransozo M.L., Fernandes C.S., Da Silva S.M.J. and Fransozo A. (2011) Early juvenile development of Armases rubripes (Rathbun 1897) (Crustacea, Brachyura, Sesarmidae) and comments on the morphology of the megalopa and first crab. Invertebrate Reproduction and Development 55, 53-64. doi: 10.1080/ 07924259.2010.548645.

Negreiros-Fransozo M.L., Fransozo A., Gonzalez-Gordillo J.I. and Bertini G. (2002) First appraisal on releasing and reinvasion of decapod larvae in a subtropical estuary from Brazil. Acta Limnologica Brasiliensia 14, 87-94.

Negreiros-Fransozo M.L. and Fransozo V. (2003) Morphometric study of the mud crab, Panopeus austrobesus Williams, 1983 (Decapoda, Brachyura) from a subtropical mangrove in South America. Crustaceana 76, 281-294. doi: 10.1163/156854003765911685.

Negreiros-Fransozo M.L., Wenner E.L., Knott D. and Fransozo A (2007) The megalopa and early juvenile stages of Calappa tortugae Rathbun, 1933 (Crustacea, Brachyura) reared in laboratory from neuston samples. Proceedings of the Biological Society of Washington 120, 469-485. doi: 10.2988/0006-324X(2007)120[469:TMAEJS]2.0.CO;2.

Paul R.K. (1981) The development of a fishery for portunid crabs of the genus Callinectes (Decapoda, Brachyura) in Sinaloa, Mexico. Technical 
Cooperation Officer, Overseas Development Administration, London, Final Report, 78 pp.

Paula J. (1988) The larval and post-larval development of Pennant's swimming crab, Portumnus latipes (Pennant) (Brachyura, Portunidae), reared in the laboratory. Crustaceana 55, 202-216. doi 10.1163/156854088X00537.

Paula J. and Dos Santos A. (2000) Larval and early post-larval stages of the crab, Xantho pilipes A. Milne-Edwards, 1867 (Crustacea, Decapoda, Xanthidae), reared under laboratory conditions. Invertebrate Reproduction and Development 38, 253-264. doi 10.1080/07924259.2000.9652458

Paula J. and Hartnoll R.G. (1989) The larval and post-larval development of Percnon gibbesi (Crustacea, Brachyura, Grapsidae) and the identity of the larval genus Pluteocaris. Journal of Zoology 218, 17-37. doi: 10.1111/j.1469-7998.1989.tbo2522.x

Pinheiro M.A.A. and Fransozo A. (1998) Sexual maturity of the speckled swimming crab Arenaeus cribrarius (Lamarck, 1818) (Decapoda Brachyura, Portunidae), in the Ubatuba littoral, São Paulo state, Brazil. Crustaceana 71, 434-452. doi: 10.1163/156854098Xoo536.

Ragionieri L. and Schubart C.D. (2013) Population genetics, gene flow, and biogeographical boundaries of Carcinus aestuarii (Crustacea: Brachyura: Carcinidae) along the European Mediterranean coast. Zoological Journal of the Linnean Society 109, 771-790. doi: 10.1111/bij.12099.

Rajabai K.G. (1959) Studies on the larval development of Brachyura I. The early and post larval development of Dotilla blanfordi Alcock. Annals and Magazine of Natural History 13, 129-135.

Rajabai Naidu K.G. (1954) The post larval development of the shore crab Ocypoda platytarsis M. Edwards and Ocypoda cordimana Desmarest. Proceedings of the Indian Academy of Sciences, Section B 40, 89-101.

Rieger P.J. and Beltrão R. (2000) Desenvolvimento juvenil de Cyrtograpsus angulatus Dana (Crustacea, Decapoda, Grapsidae), em laboratório. Revista Brasileira de Zoologia 17, 405-420.

Rieger P.J. and Nakagawa C. (1995) Desenvolvimento juvenil de Chasmagnathus granulata Dana, 1851 (Crustacea, Decapoda, Grapsidae) em laboratório. Nauplius 3, 59-74.

Rodrigues M.D. (1997) Desenvolvimento larval e juvenil de Panopeus rugosus A. Milne Edwards, 1889 e de Hexapanopeus heblingi sp. n e juvenil de Panopeus occidentalis de Saussure, 1857 (Crustacea Decapoda, Xanthidae) em laboratório. PhD thesis. Setor de Ciências Biológicas, Universidade Federal do Paraná, Curitiba, Brazil.

Rodríguez A. and Paula J. (1993) Larval and postlarval development of the mud crab Panopeus africanus A. Milne Edwards (Decapoda: Xanthidae) reared in the laboratory. Journal of Crustacean Biology 13, 296-308. doi: 10.1163/193724093Xooo84.

Román-Contreras R. (1986) Análisis de la población de Callinectes spp. (Decapoda: Portunidae) en el sector occidental de la Laguna de Términos, Campeche, México. Anales del Instituto de Ciencias del Mar y Limnología 13, 315-322. http://biblioweb.tic.unam.mx/cienciasdelmar/instituto/1986-1/articulo207.html.

Sahoo D., Panda S. and Guru B.C. (2011) Studies on reproductive biology and ecology of blue swimming crab Portunus pelagicus from Chilika Lagoon, Orissa, India. Journal of the Marine Biological Association of the United Kingdom 91, 257-264. doi: 10.1017/ Soo25315410000354.

Santos S. and Negreiros-Fransozo M.L. (1995) Morphometric relationship and maturation in the Portunus spinimanus Latreille, 1819 (Crustacea, Decapoda, Portunidae). Revista Brasileira de Biologia 55, $545-553$.
Santos S. and Negreiros-Fransozo M.L. (1996) Maturidade fisiológica em Portunus spinimanus Latreille, 1819 (Crustacea, Brachyura, Portunidae) na região de Ubatuba, SP. Papéis Avulsos de Zoologia 39, $365-377$.

Santos S. and Negreiros-Fransozo M.L. (1997) Fecundity in the swimming crab Portunus spinimanus Latreille, 1819 (Decapoda, Portunidae) from Ubatuba, Brazil. Interciencia 22, 259-263.

Santos S. and Negreiros-Fransozo M.L. (1999) Reproductive cycle of the swimming crab Portunus spinimanus Latreille (Crustacea, Decapoda, Brachyura) from Ubatuba, São Paulo, Brazil. Revista Brasileira de Zoologia 16, 1183-1193

Santos S., Negreiros-Fransozo M.L. and Fransozo A. (1995) Estructura poblacional de Portunus spinimanus Latreille, 1819 (Crustacea, Brachyura, Portunidae) en la ensenada de la Fortaleza, Ubatuba (SP), Brasil. Revista de Investigaciones Marinas 16, 37-44.

Sforza R., Nalesso R.C. and Joyeux J.C. (2010) Distribution and population structure of Callinectes danae (Decapoda: Portunidae) in a tropical Brazilian estuary. Journal of Crustacean Biology 30, 597-606. doi: 10.1651/09-3223.1.

Shen C.J. (1935) An investigation of the post-larval development of the shore-crab Carcinus maenas, with special reference to the external secondary sexual characters. Proceedings of the Zoological Society of London 1935, 1-33.

Sotelo G., Morán P. and Posada D. (2009) Molecular phylogeny and biogeographic history of the European Maja spider crabs (Decapoda, Majidae). Molecular Phylogenetics and Evolution 53, 314-319. doi: 10.1016/j.ympev.2009.05.009.

Stuck K.C. and Truesdale F.M. (1988) Larval development of the speckled swimming crab, Arenaeus cribrarius (Decapoda: Brachyura: Portunidae) reared in the laboratory. Bulletin of Marine Science 42, $101-132$.

Taissoun E.N. (1973) Biogeografía y ecología de los cangrejos de la familia 'Portunidae' (Crustaceos Decapodos Brachyura) en la costa Atlántica de América. Boletín del Centro de Investigaciones Biológicas Universidad del Zulia 7, 7-23.

Vergamini F.G. and Mantelatto F.L. (2008) Microdistribution of juveniles and adults of the mud crab Panopeus americanus (Brachyura, Panopeidae) in a remnant mangrove area in the southwest Atlantic. Journal of Natural History 42, 1581-1589. doi: 10.1080/ 00222930802109157 .

Vieira R.R.R. (2000) Desenvolvimento larval e juvenil de Hexapanopeus caribbaeus (Stimpson, 1871) (Crustacea, Decapoda, Xanthidae), em laboratório. MSc dissertation. Instituto de Biociências, Universidade Estadual Paulista, Botucatu, Brazil

and

Yatsuzuka K. and Sakai K. (1980) The larvae and juvenile crabs of Japanese Portunidae (Crustacea, Brachyura). I Portunus (Portunus) pelagicus (LINNÉ). Reports of the USA Marine Biological Institute, Kochi University 2, 25-41.

\section{Correspondence should be addressed to:}

M.L. Negreiros Fransozo

NEBECC (Group of studies on crustacean biology, ecology and culture), Department of Zoology, Biosciences Institute, São Paulo State University, 18618-970 Botucatu, São Paulo, Brazil

email: mlnf@ibb.unesp.br 